\title{
Witches' zoopsychonavigations and the astral broom in the worlds of Croatian legends as (possible) aspects of shamanistic techniques of ecstasy (and trance)
}

\author{
Suzana Marjanić
}

I shall attempt to interpret witches' zoopsychonavigations in the worlds of Croatian legends as (possible) aspects of shamanistic techniques of ecstasy (and trance), in the framework of which I shall be trying to designate the concept of zoopsychonavigation as the border of permeation between shamanistic ecstatic experiences and the witches' experience of lethargy.

In addition to the above concept of zoopsychonavigation, I establish equally possible contacts between witchcraft and shamanism on the basis of the mythem about the mutual agon between shamans as well as between witches, the distinctive features of their birth (for example, their birth in a caul), the axis mundi topos - the mythic geography of mountains and trees (the parallelism between the shamanistic tree and the fairies' tree), the use of hallucinogenic plants that have been noted in the practices mentioned, as well as the light-enhanced hypostases of the witches' bodies in the context of Eliade's attribution of the shaman as "a master over fire".

Taking as a starting-point the book Mythic Images and Shamanism: A Perspective on Kalevala Poetry in which Anna-Leena Siikala, emphasises, among other points, that "shamanism is not a religion, but rather a complex of rites and beliefs existing within different religions", ${ }^{1}$ I shall consider witches' zoopsychonavigations in the worlds of Croatian legends as (possible) aspects of shamanistic techniques of ecstasy (and trance). In this framework, I try to designate zoopsychonavigation as the border of permeation between shamanistic ecstatic experience and the witches' experience of lethargy. I shall be endeavouring in the possible search in question to achieve a theoretical peaceful and active co-existence between two contradictory concepts - Klaniczay's hypothetical concept of a transition from shamanism to another belief system dominated by witchcraft ${ }^{2}$ and Gustav Henningsen's contradictory concept, which assumes that European witchcraft developed out of a shamanistic system of which it was an "important and integrated part". ${ }^{3}$ I admit

The article was prepared for the journal Studia ethnologica Croatica (Vol. 17, 2006) in the Croatian language, and was written for the conference Shamanism: a Theoretical Construct or a Living Tradition, organised by the Department of Ethnology and Cultural Anthropology of the Faculty of Arts in Zagreb and the Department of Ethnology and Cultural Anthropology of the Faculty of Arts in Ljubljana, held in Motovun in Istria on 25 June 2004.

1 Siikala 2002: 43.

2 Klaniczay 1984: 413, 415.

3 Henningsen 1991/1992: 301.

One should also emphasise here the research done by Éva Pócs, who shows that the roots of witchcraft - thinking of the witchcraft of Central and South-eastern Europe - lie in so-called European shamanism. In other words, this author sets forth from Eliade's differential guidelines on shamanism in the broad sense and on central shamanism - the shamanism of Siberia and Central Asia (Pócs 1999: 13-14). 
Witches' zoopsychonavigations and the astral broom in the worlds of Croatian legends ......

that the assertion in question is somewhat paradoxical, due to the fact that the figure of the paradox nevertheless continues to be, it seems to me, a fundamental poetic figure of witchcraft imaginings within the framework of the European witchcraft studies concept. ${ }^{4}$

\section{The psychoanalytical paradigm or "comprehending mental illness similarly to comprehending witches"5}

To start with, let us briefly scrutinise certain joint paradigms within which witchcraft and shamanism are incorporated, in the framework of which I shall place the emphasis on the psychoanalytical paradigm. For example, numerous scholarly disciplines - folklore research, ethnology, anthropology, archaeology, gender studies, history, performance studies, psychology, religious studies ${ }^{6}$ - are interested in shamanism, and equally in witchcraft. Shamanism and witchcraft are also equally linked by their use as terms; in other words, the term shaman is used in anthropology partly in order to avoid the sensationalist or negative connotation of the term witch and witch-doctor. ${ }^{7}$ Points of contiguity are revealed, of course, in psychoanalytical paradigms, since psychopathological phenomena are often attributed to the abstract figures of the shaman and the witch. ${ }^{8}$ Shamanism as a "mental disturbance" (mainly in connection with schizophrenia and epilepsy) - or to use the more precise syntagm - a state with symptoms of mental suffering, was also interpreted, beside other ethnographers, by Åke Ohlmarks, the last investigator to favour explaining shamanism by Arctic hysteria, by his differentiating definition of Arctic and sub-Arctic shamanism, concluding that shamanism is an exclusively Arctic phenomenon that emerges under the influence of the cosmic environment on the mental instability of inhabitants of polar regions. Namely, according to his interpretation, for example, excessively cold, long nights, desert solitude, and a lack of vitamins affect the nervous system of Arctic inhabitants, causing either Arctic hysteria (meryak, menerik) or shamanic trance. ${ }^{9}$ However, Eliade stresses that similar psychopathic phenomena - including cataleptic trance (separation of the soul from the body) - are actually found everywhere (geographically). ${ }^{10}$

4 Concerning the paradox of solving the shaman enigma cf. Harvey 2003: 1-3.

5 Szasz 1982: 17.

${ }^{6}$ Cf. Harvey 2003: 1.

7 Harner 1976a: XI.

8 On the criticism of psychoanalytical interpretations which attributed psychopathological phenomena to witches through the claim that witches were mentally disturbed women, whose illness neither well-intentioned Inquisitors nor great ignoramuses managed to diagnose cf. Szasz 1982: 111. As stated by Penelope Shuttle and Peter Redgrove, we are speaking of 9 million menstrual murders, since the proportion of executed women in relation to men in the witch hunts was in a ratio of 100:1 (Shuttle, Redgrove 2002: 192, 197).

Beside the psychoanalytical paradigm, the abstract figures of the shaman and of the witch are also in the same way linked by the inquisitorial methods of the Christian missionaries, who were not indulgent towards the shamans either, almost completely rooting out shamanism during the $19^{\text {th }}$ century: for example, "it was even a crime to possess a drum, but some trance techniques managed to exist" (Stutley 2003: 65).

9 Eliade 1974: 24.

On fasting as a type of physical mortification resorted to by early aspirants to spirituality from the aspect that undernourished persons usually suffer from neuroses, depression, hypochondria and anxiety, and visions cf. Huxley 2001:142-146. Similarly, Anna Reid adds that Siberian shamans undertake soul-journeys in a state of trance, which they achieve through dance, fasting, or the ingestion of hallucinogenic plants (Reid 2003:5). For example, Tokarev quotes numerous ethnographic sources that also interpret shamans as persons with a tendency towards epilepsy (Tokarev 1978: 291).

${ }^{10}$ Eliade 1974: 27. 
Within the framework of the deeper stages of altered states of consciousness that are attributed to shamans and witches, the two most powerful forms of hallucinogenic experience are manifested in transformations into animals and a sense of floating, ${ }^{11}$ which, as I will explain later, I comprehend as zoopsychonavigations. In this respect, Richard Noll uses the term shamanistic state of consciousness (consequently, in the above context - a more specific term than altered states of consciousness) - which he adopts from the book The Way of the Shaman (1980) by Michael J. Harner - thus denoting that which anthropologists call a séance, trance, or ecstasy, thereby negating the psychopathological interpretation of shamanism, emphasising its psychotherapeutic techniques. ${ }^{12}$ Here, of course, we must return to the points of contact and differences between psychoanalysis and shamanism - or in Lévi-Strauss' definition: "In the schizophrenic cure the healer performs the actions and the patient produces his myth; in the shamanistic cure the healer supplies the myth and the patient performs the actions." ${ }^{13}$

Points of contiguity between shamanism and psychology are also realised in ecopsychology (the conjunction between psychological and ecological paradigms), which is practised today, for example, by Leslie Gray, an ecopsychologist and shamanistic consultant, on the path of Theodor Roszak's book The Voice of the Earth (1992). ${ }^{14}$

In the same way, the points of contact between witchcraft and shamanism are effectuated today in neo-shamanism, which encompasses three paradigms - Wicca, Druidism and Paganism - since, for example, some adherents of Wicca designate their own religion as "Shamanic Wicca", "Shamanic Craft" and "Wiccan-shamanism", ${ }^{15}$ just as Tanya Luhrmann does, and representatives of Wicca often state that it derives from pre-historic European shamanism. ${ }^{16}$ This idea has been extensively popularised by the Egyptologist, Margaret Murray, who stressed in her book The Witch Cult in Western Europe (1921) that the victims of witchcraft courts practised the survivals of pagan religion, ${ }^{17}$ whose followers worshipped Cernunnos, the horned god (a Gallic deity whose name covers the meaning the one who has the top of the skull like a stag). ${ }^{18} \mathrm{He}$ was known in Rome under the name Janus, or Dianus, while Frazer described him in the first chapters of The Golden Bough. Murray explained that Diana was in fact the female form of that name (Janus Dianus) and figured throughout Europe as the leader of the witches, so that the cult was called the $D i$ anic Cult. ${ }^{19}$ In studying the possible correspondence between witchcraft and shamanism, I had access, of course, to the book, The Spiral Dance, by Starhawk, one of the best-known contemporary witches, who states that the religion of witches is a shaman religion and,

\footnotetext{
${ }^{11}$ Dowson, Porr 2001: 171.

${ }^{12}$ Noll 1983: 443-444.

Richard Noll's terminological intervention in the shamanistic state of consciousness ties in with Eliade's aphoristic explication: "(..) though the shaman is, among other things, a magician, not every magician can properly be termed a shaman" (Eliade 1974: 5).

${ }^{13}$ Lévi-Strauss 1963: 201.

${ }^{14}$ Cf. Gray http. and Leslie Gray's interview, in which she explains that ecopsychology has its roots in shamanism (Gray 1995: 172-182).

${ }^{15}$ Wallis 2001: 214.

${ }^{16}$ Luhrmann 1989: 134, 329.

${ }^{17}$ Cf. Wallis 2001: 214-215.

${ }^{18}$ Chevalier, Gheerbrant 1987: 228.

${ }^{19}$ Cf. Eliade 1981: 99.
} 
as such, allocates spiritual value to ecstasy. ${ }^{20}$ For example, Marina Milićević Bradač links the very figure of the horned deity, Cernunnos, with the ideosphere of shamanism, establishing identification between the shaman drum and the stag that leads shamans into the other world. ${ }^{21}$ In that way, invoking Eliade, she states that the drum is an essential part of shaman equipment and that, the Yakuts and Buryats, for example, believe that the drum in question leads into astral journeys and call it the shaman's horse (a horse is also painted on the Altaic drum). If the drum is made of roebuck skin (as among Karagases and Soyots) then they call it the shaman's roebuck, or, as among certain Mongol tribes, it is called the black stag. ${ }^{22}$

\section{Shamanistic and witches' agon and the light-enhanced antisacrum of the witch- es' body}

In the context of legends about krsniks, ${ }^{23}$ dominated by the mythem of their struggles (agon) with štriguns (wizards) in animal form (for example, in battles between the krsnik as a white dog, a white cat, a dappled ox, and a štrigun/wizard in the form of a black dog, a black cat, or a black ox), ${ }^{24}$ Maja Bošković-Stulli points out that Eliade mentions only in passing the shaman's combativeness; "in certain Siberian traditions shamans are believed to challenge one another constantly in animal form". ${ }^{25}$ Continuing the foregoing statement, Eliade adds: "What is fundamental and universal is the shaman's struggle against what we could call 'the powers of evil'", while, in another place in his book on shamanism, he mentions that the shamans engage in struggles between themselves in the form of animals and, if a shaman's alter ego should come to grief in the conflict, then the shaman soon also dies. In addition, Eliade attributes the foregoing mythem as being extremely frequent in shamanistic belief and folklore. ${ }^{26}$

${ }^{20}$ Starhawk 2000: 30.

Cf. the computer drawing of Witchdance (2001) (http://ratko.20m.com/ira/veduta_files/slika9.htm) and the painting The Witches' Dance (1994) (http://ratko.20m.com/ira/veduta_files/slika12.htm) by the artist Krešimira Gojanović. The Witches' Dance painting is also on the cover of the Croatian translation of the book The Spiral Dance by Starhawk (translated by Lidija Zafirović).

${ }^{21}$ Milićević Bradač 2002: 31.

${ }^{22}$ Cf. Eliade 1974: 173-174.

Cf. the picture of the Tungusic shaman drum that the shaman strikes in order to catch hold of spirits and enter into an ecstatic state: "The edge of the drum skin is decorated with pictures of reindeer and the handle of the drum stick is carved into the shape of an animal's head" (Lissner 1961: photo 102). Or, as Hoppál stated, the shaman drum figured as a means of ecstatic transport and "it is not accidental that the ever-quickening drum beat resembled the drumming of horses' hooves. Apart from the drum the shamans used horse-head tipped sticks during their 'journeys"' (Hoppál 1993: 190).

${ }^{23}$ On krsnik cf., for example, the study by Maja Bošković-Stulli (2003) and the study by Zmago Šmitek (1998).

${ }^{24}$ Bošković-Stulli 1962: 531.

Andrija Bartulin notes that dead krsniks fight with kudlaks (vampires) on the island of Cres, and zoometamorphosise at the same time into cats, dogs, sheep, oxen and horses (Bartulin 1898: 267). Reporting on the island of Krk and the township of Kastav, Milčetić stated that kudlaks and krsniks can transform into all sorts of animals, most frequently into pigs, oxen and horses: "The kudlak is usually black, while the krsnik is white or mottled in colour" (Milčetić 1896: 224).

Here it would seem necessary to explain the term kudlak. Namely, according to beliefs in Istria and the immediately neighbouring regions, the kudlak (ukedlak) is a vještac, strigo, or strigon (wizard) during his lifetime, but becomes a vukodlak (kudlak) in the sense of a vampire only after death (Bošković-Stulli 2003: 20).

${ }^{25}$ Cf. Eliade 1974: 509, Bošković-Stulli 2003: 19.

${ }^{26}$ Eliade 1974: 94-95. 
The mythem about the mutual battles between the shamans can be partly placed in parallel with the mythem of the battles between witches and wizards, which Maja BoškovićStulli underscores as having been noted in the territory of Dalmatia, where witches and wizards fight between themselves, largely in the clouds when, for example, they usually fly in the form of ravens, with one group defending their village, whilst the other attacks it. ${ }^{27}$ At the same time, mutual conflict is also characteristic to moguts as village protectors since, according to the belief that each individual area has its own mogut, and that they do battle in the clouds in the form of various animals (for example, the conflict between the reddish pig and the mottled one), and, as to the victor, "his state is more bountiful and fertile" ${ }^{28}$ For example, M. Bošković-Stulli defines the core of the legend about the battle of two višćuns (wizards) in "a tempest", in the forms of a black and a white ox, as an archaic tradition "about people with the hallmarks of shamans and the function of local (clan) protectors", drawing attention to the fact that višćaks, štri(n)guns, vremenjaks, and nagromants are "polyvalent, so that they can both harm and help". ${ }^{29}$

Within the framework of the above ethical polyvalence of witches and wizards, I would draw attention to Eliade's explanation of the specialisation among individual nations between "white" and "black" shamans, within which it is not always simple to define the difference. ${ }^{30}$ In other words, he emphasises how the difference is clearly expressed among the Buryat who differentiate "white" (sagani bö) and "black" shamans (karain bö), the first of which have relations with the gods, and the second with spirits. They are also differentiated iconographically: the robes of the white shamans are white, while the others wear blue. Here he also mentions that the mythology itself of the Buryat expresses clear dualism and the fact that the bipartition of the shamans could be a secondary and even quite late phenomenon, deriving perhaps from Iranian influence or from negative evaluations of chthonic and "infernal" hierophanies which with time, of course, started to denote "demonic" powers. ${ }^{31}$ In the same way, he underscores how shamanism among the Yakut people involves a vague "dualism", since the Yakut shaman can serve in equal measure the upper and lower (the gods "below") gods, "for this 'bis below' does not always mean 'evil spirits"'. He goes on to provide the example from Altaic shamanism in which female shamans are always black, because they never effectuate the way to heaven. ${ }^{32}$

There is more on the possible dualistic interpretation of the mentioned mythem regarding the conflict between two mythical beings in Croatian oral tradition. Namely, Petar Šimunović (Brač. Guide Around the Island, 1972) interpreted the above legend about the battle between two višćuns (wizards) in a tempest, in the form of a black and white ox,

${ }^{27}$ Bošković-Stulli 1991: 148.

M. Bošković-Stulli points out that the opponents in the battles in the Istrian and Croatian Littoral region (Hrvatsko primorje) are clearly ethically differentiated: the noble krsniks fight against the wicked wizards and witches, largely in animal forms (Bošković-Stulli 1991: 149).

${ }^{28}$ Chloupek 1953: 246.

The most frequent version of the origins of the mogut is noted in the belief that if "a woman is pregnant for seven years (while some say nine), then she will give birth to a mogut" (ibid.: 241). The mogut is the village guardian on whom the produce of the land depends "and that is why the mogut contrives the weather". Drago Chloupek interprets the mogut as the agathodaimon who takes care of his village, helps the sick and defends his area from alien moguts.

${ }^{29}$ Bošković-Stulli 1975: 106, No. 85, ibid.: 148 (cf. Bošković-Stulli 1991: 148).

${ }^{30}$ Eliade 1974: 184.

${ }^{31}$ ibid.: $185-186$.

32 ibid.: 188-189. 
Witches' zoopsychonavigations and the astral broom in the worlds of Croatian legends ......

by the dualistic interpretation personifying the good and evil spirit, as a survival of Early Slavic dualistic belief "that was vital among the Croats when they came to Brač from the pagan region around the Neretva (River) during the $7^{\text {th }}$ century". ${ }^{33}$

On the trail of the shaman as "a master over fire" (M. Eliade), ${ }^{34}$ texts/legends speak of the glimmering hypostases (the sparks and glittering effects) of witches' bodies that are linked with their ornithological myth - a matter of an illuminated antisacrum (to use Rudolf Otto's term), light of the darkness, due to the manner in which they are shown in the ethics and poetics of the folklore imaginary. ${ }^{35}$ Since this is a case of verticalism (an ascent), the rising of the soul is connected with glimmering-fiery effects, but since witches are incorporated in the folklore imaginary of the light of the darkness, the epiphanies of the witches' lights produce lunar and stellar light. The connection between the witches' epiphanies mentioned and the light-enhanced modifications can be linked with the concept according to which the human soul is "fiery in nature", as Nodilo mentions in the concept of his own "pneumatology" or, more precisely - it figures as "a spark that flew off the celestial fire", concluding how the fiery genesis of the soul is not known in the Christian concept of the soul. ${ }^{36}$

It is also possible to demarcate between mythological and ecstatic interpretations of the witch personage in the same way that Zmago Šmitek fixed the boundaries between the mythological and ecstatic of the (Slovenian) kresnik, in the framework of which he takes as his starting point Ginzburg's definition of ecstatic cults tied in with archaic Eurasian shamanism. ${ }^{37}$ Let us take a brief look at one $19^{\text {th }}$-century mythological interpretation of the witch personage, according to Natko Nodilo. Namely, in the Day/Night and Summer/ Winter cosmological dualism, Nodilo defines Night as a masculine form, and Winter - as an old hag. ${ }^{38}$ Nodilo finds confirmation for the driving out of the Winter hag in the Spring

\footnotetext{
${ }^{33}$ Cf. Bošković-Stulli 1975: 149.
}

M. Bošković-Stulli refutes Radoslav Katičić's thesis that suggests that the roots of the myth about the duel between the Thunderer/Perun and the Dragon/Veles (Bošković-Stulli 1997: 77, Bošković-Stulli 2003: 32-34) can be detected in legend from the island of Brač. Namely, the author in question stresses that, in reviewing the above thesis, one would have also to take into consideration how a change could have come about in the roles between the personage of Perun's pestilential opponent, the Dragon (Snake), and the later Balkan beneficent protector, the Dragon (Snake), who protects from the malevolent enemy, the hala or lamja (also dragons) (Bošković-Stulli 2003: 34). Perhaps the solution to this enigma lies in the claim that there is an absence of division in the natural religions into (ethical) good and evil deities, since (each) deity possesses good and evil (cosmic) aspects (cf. Nodilo 1981: 451).

${ }^{34}$ In any case, shamans are more than mere "masters over fire" (Eliade providing on this track a comparison with devils in European folk beliefs), but can incorporate the spirit of fire and throw flames from the mouth, nose and their entire bodies during séances (Eliade 1974: 474).

${ }^{35}$ Cf. Marjanić 2002: 242-243 on individual examples of legend that testify to the connection between witches and glimmering hypostases. For instance, there are examples of viškas (witches) from the village of Ivčević Kosa who fly on brooms to Klek Mountain on the eve of St George's Day: "There is talk among the common folk that bright sparks can be seen in the air on that night, and that these are the viškas journeying to Klek" (Hećimović-Seselja 1985:195). Cf. Mirjam Mencej's text (2004), in which the author points out that the glittering light-effects phenomena, which are linked with the souls of the dead in the popular beliefs of the Slavs and peoples throughout most of Europe, are sometimes also interpreted as (nocturnal) witches in the region of Slovenia and in other Slavic cultures.

${ }^{36}$ Nodilo 1981: 536-537.

I have written more extensively on Nodilo's concept of the World Tree (arbor mundi), with which he also tried to link the mythem of the fiery genesis of the soul (cf. Marjanić 2004).

37 Šmitek 1998: 97.

${ }^{38}$ Nodilo 1981: 142-143, cf. Marjanić 2003.

Cf. Nodilo 1981:59-61, 192,216 on Nodilo's polysemy of the Evil of winter horrors in the figures of Mora/Vada 
(March) customs of the western and south-western Slavs, when they carried out of the village a puppet personifying Morana/Death (Mora, Morana, Morena - the deity of Winter and Death), in the figuration of an old woman, in order to drown her (smother her) or saw her up (cutting up the hag). ${ }^{39}$

Regarding the belief that when storm clouds are fired upon, witches are "hit, and fall to the earth from the clouds", Nodilo writes that he is not sure whether this belief about witches stemmed from Mediaeval demonology or whether this was a case of an original Indo-European meteorological belief. For that reason, he said, he had omitted witches from his study. ${ }^{40}$ In other words, the traces of this belief about the stormy activity of witches in folk meteorology are found in the Rigveda (II, 20,7). ${ }^{41}$ Let us look at the notation of a legend from the island of Zlarin about the alleged stormy activity of witches. The legend was written down and published under the title "They Shot Into the Tempest" and states that the army, shooting at a sudden storm, killed an old woman who - as she said in her dying agony - was supposed to destroy by hailstorms vineyards. This is her interpretation from the narration in question:

"I was /.../ in that tempest, I was sent. I was sent there, I myself wouldn't have wanted to I was sent so that we destroy by hailstorm the vineyards /.../ belonging to this one and that one - depending on who hated whom."42

\section{Zoopsychonavigation}

In the framework of the above attempt to resolve the points of contact between the abstract figures of shaman and witch, I shall try to designate the border of permeation between shamanistic ecstatic experiences and the witches' experience of lethargy through the concept of zoopsychonavigation. If we observe the concept of the shape-shifting of the soul during the temporary death of supernatural persons and mythical beings, which could be referred to as catalepsy, taking as our example a particular legend or, more precisely, a collocutor's view of a neighbour who was allegedly a mora, and who was obviously in a state of lethargy in which the pulse and breathing were virtually imperceptible: "And I called her (name), (tried to) move her, pushed her, pulled at her. All for nothing. As dead as dead can be. Upon my word, I was frightened." ${ }^{43}$ With the notion of zoopsychonavigation (psychonavigation of the soul in an animal existence), on the one hand, I observe zoometempsychosis (shape-shifting of the soul into an animal form) that takes place in the experience of lethargy among supernatural persons and mythical beings, due to the fact that metempsychosis demands a transgression through death - as a temporary death. ${ }^{44}$ In the

(Kavga) - Ruga (Baba Ruga), who are linked with the aspect of the wind and the isomorphism of the broom as the terrifying weapon of the winter monster.

${ }^{39}$ Nodilo 1981: 59, 286.

On Morana's (the aged virgin Mara) death, which occurs after the burning/burying of the Carnival puppet (Poklad, Fašnik) cf. Belaj 1998: 323-324.

${ }^{40}$ Nodilo 1981: 396-397.

${ }^{41}$ ibid.: 397, 408.

${ }^{42}$ Marks 1980: 265, No. 48, italics S. M.

${ }^{43}$ Kutleša 1993: 386, italics S.M.

${ }^{44}$ Chevalier, Gheerbrant 1987: 401 
Witches' zoopsychonavigations and the astral broom in the worlds of Croatian legends ......

same way, I take the term zoopsychonavigation also to mean witch zoometamorphoses, ${ }^{45}$ as well as riding (flying) on the backs of animals (theriomorphic vehicles) by which, for example, witches hover in the air (the binomial anatomy/iconography of the WomanAnimal) ${ }^{46}$ and, of course, incubus-like riding on men (shared by fairies and witches). ${ }^{47} \mathrm{I}$ have already mentioned that Thomas A. Dowson and Martin Porr stress that transformations into animals and a sense of floating is usually a hallucinogenic experience of deeper stages of altered states of consciousness. ${ }^{48}$

Zoopsychonavigation is, of course, also shared by shamans whose souls manifest themselves as animal shapes. In other words, shamanistic imitation of the movements and voices of animals denotes taking possession of the helping, tutelary spirits - the moment at which the shaman transforms into an animal - as is also achieved when they put on a mask or - as Eliade notes - one could speak of the shaman's new identity due to the fact that he becomes an animal-spirit and speaks, sings or flies like an animal or bird. What definitely seems important to me here is Eliade's claim: "From the most distant times almost all animals have been conceived either as psychopomps that accompany the soul into the beyond or as the dead person's new form."49 And further, when the shaman participates in the manner of becoming an animal, he establishes a situation which had existed in illo tempore when there had been a connection between the human and the animal world. The tutelary animal makes it possible for the shaman to transfigure into an animal, just as it figures as his double, his alter ego, "the shaman's soul", ("the soul in animal form"), or "the life soul". ${ }^{50}$ Shamanistic animal metamorphosis and riding on the backs of animals symbolically expresses ecstasy: temporary death is designated by the exiting of the soul from the body in an animal form. ${ }^{51}$ Eliade concluded that symbols "in relation to 'flight', and the

${ }^{45}$ M. Bošković-Stulli differentiates three types of witch transformations into animals: when they fly in the clouds; when they fight between themselves or with krsniks; and when their spirit emerges, assuming animal form (Bošković-Stulli 1991: 151). J. Lulić noted that, according to beliefs on the island of Dugi Otok, štrigas possess a wide range of transformation possibilities - for example, from zoometamorphosis (into snakes, hens, cats, sheep, goats) to metamorphosis into objects (sieves) and natural phenomena (such as the wind) (Lulić 1993: 363).

${ }^{46}$ When it is said that Isis "rides on a sow", in sacred or visionary language that means that she is riding on her fertile instincts, which include her so-called swinishness of menstruation. Namely, female genitals were called "the swine" in Greek and Latin (Shuttle, Redgrove 2002: 230).

${ }^{47}$ I wrote about fairies and witches and their incubus-like riding on men in texts in 2002 and 2004. Namely, individual narrations indicate that both witches and fairies also ride on men in their nocturnal riding, using them as horses, where the witches in this gallop assume the role of the incubus (Lat. incubare - to lie upon; those who lie upon: devils in male form), while the male who assumes the passive, that is to say - feminine role of the succubus (Lat. succubare - to lie below, to lie beneath someone, by which the position of the female in the act of love is described: they who lie below, the devil in female form) is in a state of ecstasy - a stupefaction of the consciousness. At the same time, the hypomorphic binomial horse (man) - witch is also present in the imaginary about fairies, which choose the best horse (man) to ride.

${ }^{48}$ Dowson, Porr 2001: 171.

${ }^{49}$ Eliade 1974:93.

50 ibid.: 94.

Triinu Ojamaa (1997:1) differentiates three methods of zoomorphic and ornithomorphic transformation in Siberian shamanism: objective transformation (for example, costumes symbolize a certain animal or a bird); sounding transformation (imitating sounds made by animals and birds, where the author adds that the Ostyaks have songs that denote animals and birds, but do not contain sounding imitation, regarding that as degrading for said animals and birds [cf.. Ojamaa 1997:6]); and expressive transformations (imitating the movements of animals and birds which could be "rhythmless movements, such as the turn of the body, and the wave of the hand etc., pantomime, or dances").

${ }^{51}$ Ginzburg 1991: 172. 
'riding' or the 'speed' of shamans, are figurative expressions for ecstasy, that is, for mystical journeys undertaken by superhuman means and in regions inaccessible to mankind" ${ }^{52}$ In the same way, Ginzburg explains in the book The Night Battles (I benandanti, 1966) that the trance, journeys on the backs of animals into the other world or in animal forms that ensure fertility, and participation in processions of the dead, create the pattern that evokes shamanistic rites..$^{53}$

Claude Lecouteux points out that the zoomorphic soul is an archaic pagan conception characteristic to shamanistic peoples. ${ }^{54}$ Namely, the essence of Lecouteux's book Witches, Werewolves, and Fairies: Shapeshifters and Astral Doubles in the Middles Ages (1992) is comprised of the hypothesis that we do indeed have Doubles, usually two - one material and one physical, the former having the capability of taking on an animal form or retaining a human form, while the other Double is spiritual and psychic, and also possesses the possibility of metamorphosis, but this manifests itself mainly in dreams. The (binomial) Doubles referred to above are able to reach the other world - "or any place whatsoever in this world - in one or another of their forms" - during sleep, or a trance or catalepsy. ${ }^{55}$

Letuspauseforamomentonthepointofthewitch'sand mora'szoopsychonavigation. ${ }^{56}$ The witch's (as well as the mora's) ${ }^{57}$ astral, Hesperian, nyctomorphic activity is designated by transformation of the soul, separation of the soul from the body, where the body (of the woman - mora, witch) remains in the bed, while the soul achieves zoometempsychosis, with the mora and the witch figure as the psychonavigating Woman-Animal, the animal in the female (the animal as a shape-shifted soul). This is a case of the alter ego, the spiritual twin of the archetypical personage of $I$ (Woman), of the brief nyctomorphic zoomaterialisation of the soul: the soul assumes the form of an animal, which will also be maintained in the etymological proximity of the Latin words anima and animalis. ${ }^{58}$ Night is the time when her (the witch's, the mora's) animal transformation takes place, while she returns to the body (the bed) of the Woman when morning comes. In the framework of the witches' zoometempsychosis - which is included in tantric experiences and Siddhi power ${ }^{59}$ linked

${ }^{52}$ Eliade 1974: 174.

${ }^{53}$ Ginzburg 2001: 123.

Cf. the sketch by the Dutch researcher Nicolaas (Nicolaes, Nicholas) Witsen dating from 1705, which depicts a shaman (of the Siberian Evenki tribe) as half-man half-animal. Apart from being dressed in the fur of an animal, he has bear claws, wears tall horns on his head, and holds a drum in one hand and a clapper/rattle in the other (cf. Milićević Bradač 2002: 29).

${ }^{54}$ Lecouteux 2003: 51.

55 ibid.: 147-148.

Claude Lecouteux finds the roots of the shape-shifting of the soul in shamanistic concepts of the soul and interprets astral Doubles - witches, werewolves and fairies - in a really attractive and simple manner. Namely, Lecouteux points out that the term soul is not at all justified in the cited concept of the free soul (Freiseele) of the witch, werewolf and fairy, and that it is much more appropriate to use the term animus and/or if we want to be precise - the term Double or alter ego (Lecouteux 2003:103). Cf. Marjanić 2004a on folklore conceptualisations of the soul.

${ }^{56}$ I wrote about this in more detail in 1999 and 2002 texts.

${ }^{57}$ Just briefly to remind readers that, according to individual Croatian popular beliefs, only a young female can be a mora - or as the collocutors put it more juicily, a broad - but when she weds, she then becomes a witch. Namely, in some regions, for example, in Veli Iž (a settlement on the Island of Iž), the terms štriga and mora have the same meaning (cf. IEF MS 1195: 3).

${ }^{58}$ Visković 1996:57

${ }^{59}$ Mauss 1982: 101 
with shamanistic ecstasies and in the context of Eliade's remark on how, where the symbolics of flying and the mythology of the bird-soul are concerned, what is in question is universal magic ${ }^{60}$ - it is believed that they can pass through every aperture on a house in Hesperian psychonavigation (in spirito), while the dominant conviction is the belief in the possibility of their passing through a keyhole. ${ }^{61}$ For example, Mijat Stojanović noted that a spirit-vjedina comes out of the sleeping witch's body, while the body remains dead (temporary death) in the body (the body-bed): "When the first cocks crow and thus start to greet the dawn, there, a vjedina comes back, and once again enters the body." Otherwise, a vjedina who is left without a body-habitat-wrapping remains dangerous, ${ }^{62}$ and if the body of such a woman (a witch) turns upside-down in bed, her spirit/soul is incapable of achieving the return into the body-bed. ${ }^{63}$

Zoometempsychosis into a fly, which is attributed in legends to moras, witches and krsniks, through the activities of authoritative power (in Sloterdijk's definition) of ecclesiastical authorities and folk ethics, is diabolised when moras and witches are in question, but is regarded from the aspect of its supernatural features when zoometempsychosis applies to krsniks. Similar ethical differentiation of the cited animistic conceptions ${ }^{64}$ was also realised in the process of folk imagination of witches' zoometamorphoses that were diabolised, while the zoometamorphoses of krsniks, ${ }^{65}$ attained in psychonavigational struggles for a fertile year (such facilitators include "other analogous beings ranging from Slovenia to Montenegro", for example, obilnjaks, brgants, kombals, vedomacs, moguts, veds, vrimenjaks/vremenjaks, višćaks, legromants/nagromants, vjedogonjas/jedogonjas, stuhas, zduhačs) were understood as being fructiferous. ${ }^{66}$

Let us look, for example, at the zoometempsychosis of a Woman/mora (the soul) into a cat. ${ }^{67}$ Psychonavigation of a mora in the form of a cat ${ }^{68}$ summons up symbolisation

${ }^{60}$ Eliade 1974: 481

${ }^{61}$ For example, Vladimir Ardalić (1917: 306) noted down that the people of the Bukovica region believed that witches can enter through a keyhole and that they largely transform "into flying things, such as birds of every kind, and into black hens and turkeys". The witches' zoometamorphoses referred to are linked with the ornithomorphic symbolics of shamanism. Cf.legends about witches and warlocks in the clouds in ornithomorphic form - according to Bošković-Stulli (1991:148), as eagles and ravens. This is the matrix legend of cloud-flying witches and warlocks, who bring stormy weather and hail, in the framework of which M. Bošković-Stulli (ibid.) adds that "they encompass a motif from deeply archaic times, which is foreign to theological thought about witches".

${ }^{62}$ Stojanović 1852: 384

${ }^{63}$ Zečević 1981: 10

${ }^{64}$ Bošković-Stulli 1959: 223.

${ }^{65}$ M. Bošković-Stulli emphasises that the wanderings of the krsnik's spirit are mentioned much more rarely than is the case in legends about the warlock or witch (Bošković-Stulli 1991:150). But let us, nevertheless, take a look at a notation that testifies to the wanderings of the krsnik's spirit: "They say that prior to the grišnjak (the krsnik) starts to fight with the štrigas, he falls asleep lying on his back and a large, black fly, which they call the 'parina' comes out of his mouth - and then he goes to fight as far as the ninth border/i onda ide tući se čak na deveti konfin" (Ital. konfin. - boundary stone; border, boundary line) (Žiža 1913: 192).

${ }^{66}$ Bošković-Stulli 2003: 20-21.

${ }^{67}$ I wrote in more detail about the mora's zoopsychonavigations as a cat, fly or moth in a 1999 text. To take a look at a fragment of a particular legend: "And that Mada would lie down normally at night, and would then be absent. Her child would cry, and her husband would call out to her. But she looked as if she were dead." According to this narration, her husband would place her head in the position of her legs, and in the morning at dawn, "when the cocks crowed, a fly would come and buzz around the room". Of course, according to the narrative matrix about moras and in this case about a witch's zoopsychonavigation, the fly (the materialisation of the soul) could not enter the body "until the head was back in its place, and the legs as 
of the lunar and nyctomorphic animal that suffered most because of demonically denoted apantomancy in witch hunts, although it set out on its historical journey as a sacred Egyptian animal in the cult of the Goddess of the Moon Bast/et. ${ }^{69}$ Otherwise, the English words puss/pussy derive from the theonym Pasht, as the alternative name for Bastet/Bast - the Egyptian goddess who was revered in the form of a cat. ${ }^{70}$ Can this animal, which shared the common destiny of witches at the stake, ${ }^{71}$ be placed in the archetypical imaginary in parallelism with the animal, spiritual assistants of the shaman $?^{72}$ Pennethorne Hughes pointed out that the popular etymology of the archaic word cat, meaning a stick, may have become confused with the animal, and, in faulty interpretation, substituted by the animal - the cat. ${ }^{73}$ Let us take a brief look at the shaman's animal helpers. While the shaman can have numerous guardian spirits in human form, he possesses only one spirit helper representing each species of animal, which Uno Harva calls the soul-animal. On his journey to the supernatural, the shaman's soul takes the form of this sort of animal helper. ${ }^{74}$

Now we come briefly to the materialisation of the soul as a butterfly. According to Nodilo's concept of pneumatology, the soul among the Slavs figures as a bird, ${ }^{75}$ while it was a butterfly among the ancient Greeks (Gk. psyche - soul, butterfly). Nodilo assumed that the deeper historical beginnings of the soul-butterfly should, nevertheless, be sought for in Lithuanian beliefs, where the soul was conceived as both a bird and a butterfly (moth): "When a moth enters a house and flies around a candle, Lithuanian women say that someone has died and that that person's soul is making its rounds (Grimm, Deutsche Myth., s. 692)." ${ }^{76}$ Moving on from this belief, Nodilo adds that the conception of the butterfly-soul belongs to the Indo-European matrix. Milan Budimir established that the terms vještica (witch) and vukodlak were also used for the Death's Head moths (Acherontia atropos) that fly around light at night, and that the similar small moth is called a witch (vještica), while the conception of the soul of a departed forebear in the form of a moth (Seelenschmetterling), which is know from the Minoan epoch, had "an essential role in that semantic evolution"..$^{77}$ The belief that the moth was a herald of death, and sometimes the countenance of death, derived from the concept of the moth as the deceased's soul. ${ }^{78}$

they were. And then the fly would enter into her, and only then would she respond. And then they knew that she was a witch. And her husband gave her a sound beating" (Bošković-Stulli, Marks 2002: 511, No. 68). Jakov Mikac wrote that he had noted a belief in Brest in Istria that štrigas cannot be seen because "they transform into a spirit, a fly, a mouse, a hair etc." (Mikac 1934: 196) and how domestic animals can often become štrigas and vukodlaks (ibid.: 197). Or: the spirit can exit the body in the form of a fly (Milčetić 1896: 236).

${ }^{68}$ Cf., for example, Bošković-Stulli 1959: 143, No. 139, Milčetić 1896: 236, Pederin 1976: 282, No. 15.

${ }^{69}$ Douglas Hill reminds readers how, during the time of witch hunts, pets - cats, squirrels, spiders, mice and frogs - could be declared to be the witches' demons "particularly if an old woman was in question who lived alone and kept animals to keep her company" (Hill 1998: 38). Cf. the connection between cats and witches according to Bošković-Stulli, Marks 2002: 510-511, No. 67.

${ }^{70}$ Sax 2001: 58.

${ }^{71}$ ibid.: 60 .

${ }^{72}$ Cf. Musi 1997: 15.

${ }^{73}$ Hughes 1975: 156.

${ }^{74}$ Siikala 2002: 234.

${ }^{75}$ Although the conception of the soul in the form of a bird is widely disseminated in Christian literature, Lecouteux states that the zoomorphic soul is an archaic conception characteristic to shamanistic peoples (Lecouteux 2003: 51).

${ }^{76}$ Nodilo 1981: 509.

77 Budimir 1966: 272.

${ }^{78}$ Gura 1997: 487. 
One should add that the Church initially opposed the popular beliefs about the flights of Hesperian women, this being testified to by the Canon Episcopi (around the year 900) that came down against the popular belief according to which malevolent women "with the pagan goddess Diana and a large band of women ride upon animals during the night hours and travel across great distances in the wee hours of the night". ${ }^{79}$ The Canon Episcopi explicitly states that this is a lie and that the unfaithful women experience the cited psychonavigation in their sleep, and definitely not when they are awake. Consequently, it is notable that this Church document refutes the realistic basis of the conception of night flight by women-sorceresses and that of the bewitched transformation of one creature into another. However, $13^{\text {th }}$ and $14^{\text {th }}$ century Inquisitors managed to cast aside this document, ${ }^{80}$ and declared the Truth to be quite the opposite - anyone who did not believe in the reality of the Hesperian acts referred to was also negating the ostensible "Truth" of the Church.

\section{The witches' psychonavigational broom}

Within the framework of the witches' psychonavigational astral riding, the astral broom - which they usually choose as their astral and psychic vehicle in the attainment of the ecstasy technique - can be seen as an isomorphism of a phallomorphic applicator for the hallucinogenic ointment made from an atropine-containing plant, and as an isomorphism of the shaman's horse-headed stick (with a horse-head shaped handle), used by the Buryat shamans in their ecstatic dances. In any case, it is called the horse (and is not unlike the handle of the witches' broom) and figures as some sort of hobby-horse, ${ }^{81}$ upon which the shaman rides, travelling into the other world or, in Eliade's definition - the symbolic "riding" expressed the departure from the body, the "mystic death" of the shaman. It should be mentioned that Ginzburg stresses that the suggestion that the dances and seasonal ceremonies should be interpreted as a derivation of shamanistic rituals, on the basis of elements such as, for example, the use of the stick with the horse's head (the hobby-horse), does not seem to be sufficiently well-founded. ${ }^{82}$

A modern witch called Gwydion defines the belief that witches fly on brooms as an obvious instance of misunderstanding of the magical-poetic codes that indicate shamanistic ecstasy and visionary flight of the spirit. ${ }^{83}$ That is probably so since, according to individual Croatian popular beliefs, witches do not achieve ecstatic take-off by means of their brooms, but leave them in their beds as an alter ego. ${ }^{84}$ In the distant year of 1846, Luka Ilić Oriovčanin published the belief according to which witches rubbed fairy (vilonjska) ointment in their armpits and on the soles of their feet prior to their flying out of the window,

${ }^{79}$ Bayer 1982: 63 .

${ }^{80}$ ibid.:64-65, cf. Levack 1995: 46-48.

${ }^{81}$ On this point, the horse-headed sticks are called "horses" by the Buryat, while the drum of the Altaic shamans is called also called "horse"; cf. Eliade 1974: 175, 407-408, 467 (cf. Chevalier, Gheerbrant 1987: 272).

The Buryat sticks can represent a horse, a snake or a human being, each one of which is used for a particular type of astral journey, either as a symbol of authority and mastery, or as a weapon for punishing offenders (Stutley 2003: 48).

82 Ginzburg 1991: 195.

${ }^{83}$ Gwydion 1994: 58.

${ }^{84}$ However, M. Bošković-Stulli pointed out that a weak echo of the international theological conception from the witch trials has been retained in Croatia, the one that witches fly to their covens at night, leaving an object (a broom, for example) in their place in their houses (Bošković-Stulli 1991: 150). 
and left their broom in their place in the bed before achieving psychonavigation. ${ }^{85}$ Divna Zečević noted a legend in Remete (an outer suburb of Zagreb) that led her to believe that the broom was a prop, but also a synonym for sorceresses (coprnice) and sorcerers (coprnjaci), "so that it replaced the woman in the bed and made her visible and present to her husband, even when she was on a nocturnal trip on Sljeme"86 (the highest peak of the Medvednica Mountain Range near Zagreb). Still, there are numerous legends testifying to witches' psychonavigations on brooms or some other astral and psychic vehicle. ${ }^{87}$ In any case, we need only to recall Mephistopheles' intriguing question to Faust: Wouldn't you like to have a broomstick? (J. W. Goethe: Faust, 3835).

One also finds riding on theriomorphic vehicles in shamanism. For example, there is one particular segment of the shamanistic ritual among the Altaics: a few steps away from the tent (the yurt) there stands a scarecrow in the shape of a goose that the shaman straddles and then waves his arms as if flying, while his song is about flying above white and blue clouds, and how he climbs up into the heavens on this bird.8

The text entitled Broomstick History (http.), which achieves cyber-flight in the Internet imaginary of the witch's broom, indicates that the broom-stick denoted tantric erotic sitting to the witches, which would connote the symbolisation of the phallic divinity of the broom. Riding on a broom, similarly to the above-mentioned fairy/witch riding on a horse, can denote the erotic, feminine active position that was often denounced as perversion, in which the male was in the position or perhaps the role of a horse. The witch's position on the broom is described erotically and picturesquely by the verb to ride and its variants to mount, to straddle (the broom), and to spread one's legs, which conjure up the iconogram of sexual practice. I would also like to refer to Róheim's interpretation of shamanistic ecstasy, in which he could not resist the temptation to explain in the Freudian manner the shamanistic flight and ascent (ascensus): "(...) a flying dream is a dream about the erection, that is, the body represents the phallus in such dreams. Our hypothetical conclusion would be that the dream about flying is the nucleus of shamanism." 89

And while wings (krila i okrilje) were allocated to fairies as an ornithomorphic aid in psychonavigation, verticalism, and the angelisation of eroticism (cf. Marjanić 2004), an astral vehicle in the form of a naturalistic phallusoid broom-handle (or stallion) pertained to the witches. In addition to the fact that Croatian witches - or, perhaps more appropriately - witches in Croatia, flew on brooms, they could also achieve psychonavigation on other vehicles, while the following astral aids are usually noted in legends: cherry wood brooms, ${ }^{90}$ shafts, T-shaped windlasses, spindles, ${ }^{91}$ ravulje (dračevile - two-pronged bramble forks), billhooks, mortars (stupa, avan), ${ }^{92}$ churns (a narrow, tall wooden vessel in which butter was churned $)^{93}$ and, for example, even fire pokers, barrels, and tubs, ${ }^{94}$

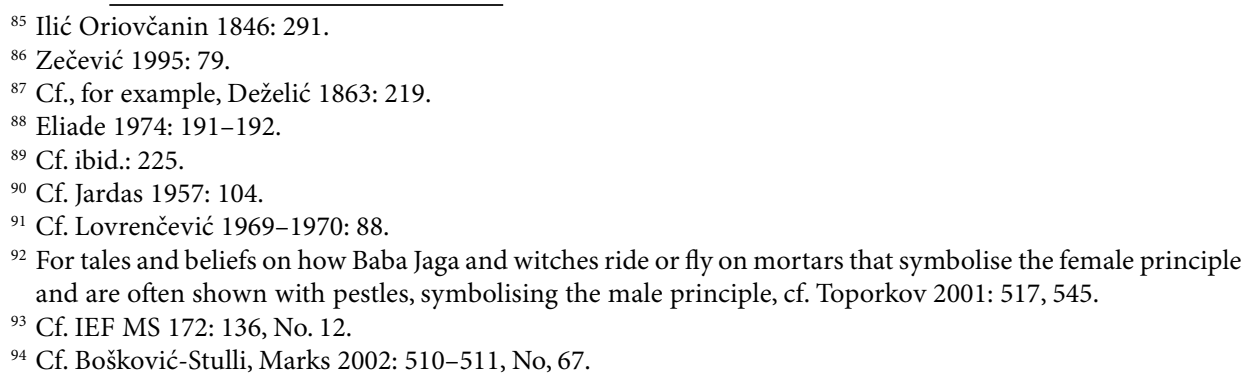


along with noted animal psychonavigation vehicles - for example, male goats. ${ }^{95}$ It should be stressed at this juncture that the witches in Croatian oral legends also choose animals as astral vehicles, in addition to the above, while the horse figures as the most frequently mentioned theriomorphic vehicle or, as in Kompolje - the aforementioned male goat. The notion of the witches' psycho/navigation on brooms/broomsticks, hoes and shovels probably emerged from archaic rituals in which the dancers used tools with long handles as wooden horses. ${ }^{96}$

In order to avoid confusion - the broom's triangle was located in front of the witch's vulva in flight, although the brushy part of the broom was usually also located behind the witch's buttocks in iconographic depictions of the Hollywood imagination. For example, in Goya's picturesque imagination of witches' flight (Fine Teacher!, Capricho 68, 17971798), ${ }^{97}$ there are two naked witches with long, flowing hair seated on one broom, where the broom's triangle is turned forward; an old witch is in the role of leader of the astral navigation. However, in the Harry Potter cycle of films, Harry is shown riding on a broom whose brushy triangle is behind the young rider. Kevin Carlyon, a British White Witches high priest, criticised this film imagination as lacking authenticity since "woodcuts from the $16^{\text {th }}$ and $17^{\text {th }}$ centuries show broomsticks being ridden with the brush part in the front" of its levitating rider. ${ }^{98}$

The broom that has the function of cleaning, chasing away and destroying the old (thus, also the unclean) by new (pure) forces is the symbol of the revolutionary corrective, since, just as the broom clears away dirt and rubbish (where material cleaning is involved), the broom in the metaphorical sense also projects spiritual cleansing, by which, as Marijan Stojković tells us - in the article "Room-dust, rubbish, broom and rubbish dump" from 1935, which to date is the only Croatian study on symbolisation and the imagination of the broom and the rubbish dump - "(it) sweeps or sweeps away evil, the malevolent spirit, misfortune, spells, disease and death; that is a ritual and magical cleansing"..$^{9}$ Through its structure, the broom unites the male principle - the phallic symbol upon which the witch rides-flies - and the female principle of the triangular (delta-shaped) apex, and in that way symbolically demonstrates the antithesis between the pure (phallic handle in the hands) and the impure, dangerous (female triangle of the sweeping broom). ${ }^{100}$ Another interpretation that is near to the foregoing is the one in which symbolisation of male pubic hairs, as the regenerative symbol of fertility and re-birth, are read off from the phallusoid handle in the broom's triangular brush.

Natko Nodilo pointed out - unfortunately, without citing his source - that the broom was reputed as the warlike symbol of winter, the "terrible weapon of the wintry behemoth"101 among Indo-European peoples. As with witches, for whom the broom is their astral vehicle, the broom is also an attribute of the mora (admittedly, here it is a

${ }_{95}$ Grčević 2000: 503.

${ }^{96}$ Hill 1998:10.

In addition, as Margaret A. Murray reported, witches in the Middle East rode on palm branches (Murray 1970: 89).

${ }^{97}$ Cf.. Buchholtz 1999:82 (cf. Fig. No. 2).

${ }^{98}$ Davis 2001, http.

${ }^{99}$ Stojković 1935: 25.

${ }^{100}$ Radenković 1996: 150-151.

${ }^{101}$ Nodilo 1981:61. 
matter of the broom as an apotropaic against the mora's influence), which is symbolically linked with the aspect of flight and wind. I would remind readers of the fact that the Mesopotamian (Babylonian-Assyrian) name of the archedemon Lilitu (the Assyrian storm demon) denotes the spirit of the wind, ${ }^{102}$ with which one aspect of the mora's and the witch's identity card is connected. In Southern Slavic folk beliefs, the broom is often denoted as an apotropaic against the mora and the witch, with a significant instruction that it is necessary to turn the broom upside-down behind the door, which intensifies its apotropaic power: "driving out Evil with Evil". ${ }^{103}$ Or there is Nodilo's mythological interpretation: when a broom is turned upside-down behind a door, it overturns the Aryan weapon and insignia of the avaricious and gluttonous $M /$ mora and the storm-borne Ruga, and thus thwarts their activity. ${ }^{104}$

The astral broom, a significant iconographic instrument in the witch's demonic technique, is read off either in the symbolism of a purifying (material and spiritual) corrective, or in Nodilo's definition - as a warlike symbol of wintry horrors (stormy seas), or in the context of tantric copulation; the shaft, the T-shaped winch, and the spindle - which is connected with spinning and weaving techniques - links witches with the goddesses of destiny (weaving); two-pronged bramble forks and the billhook - as agricultural tools - place witches in the context of the vegetation cycle; the mortar and pestle and the churn - as utensils associated with the preparation of Good - give her the role of bread-winner of the family; while the poker links the role of the witch with the cult of the hearth, as the sacred place where the witch/old woman, as guardian of the holy fire/the hearth, practices the pagan (village, peasant) religion/magic, since traditional witchcraft relates to the cult of vegetation and livestock fertility. Mircea Eliade drew attention to the gynaecomorphic symbolics of the hearth (the hearth= the vulva) as the seat of fire and that fire or the divine (spiritual) fire is of "demonic" origin "since, according to certain ancient beliefs, it comes about through sorcery in the sexual organ of the witch". ${ }^{105}$

Apart from that, the hearth in Croatian oral literary legends about witches is shown to be the place where our demonic flyers keep their flying balm. ${ }^{106}$ For example, Ivan Milčetić noted on the Island of Krk that viške/štrige (witches) rub themselves with balm that they store in a pot below the hearth, ${ }^{107}$ before they take to the air. A legend from the area of Bukovica tells of an old witch who stripped naked; she picked up a staff and struck with it "on the left-hand hearth trestle by the fire and (started) enticing as if she was tempting a ram before her. When a small pot the size of a walnut emerged, the old woman smeared (the contents) all over her from head to toe and said: 'Not of wood nor of stone, but under the walnut-tree below Promina'" (one of the mountains in the Dinaric Mountain Range - the highest peak at $1146 \mathrm{~m}) .{ }^{108}$ Such imaginings about witches' balm are (largely) linked with the hearth cult (lararium) that figures as the seat

\footnotetext{
${ }^{102}$ Graves, Patai 1969:67.

${ }^{103}$ Stojković 1935:28.

${ }^{104}$ Cf. Nodilo 1981:59-61,192.

${ }^{105}$ Eliade 1983: 40, 214.

${ }^{106}$ Lecouteux stressed that there were three traditions in witches' flight: flight with animals (which became entrenched around the year 1000); with the aid of satanic balm; and fantastic riding on a stick, "a tradition that grew to include a broomstick" (Lecouteux 2003: 84-85).

${ }^{107}$ Milčetić 1896: 233.

${ }^{108}$ Ardalić 1917: 306.
} 
of the clan's home idols, the souls of forebears. ${ }^{109}$ In the regions of the Southern Slavs sacrifices in the form of human blood were made to the hearth trestle (prijeklad, zaklad, konj, nadžak - the rack against which the logs were leaned) ${ }^{110}$ as the clan idol, according to which the future was foretold, depending on whether the blood boiled or not. It was taken as an unfortunate sign for the clan if the blood boiled; they then abandoned the house and the hearth trestle-idol. ${ }^{111}$ Linking the witches' balm in folklore imaginings with the hearth topos can be denoted as a survival of pagan religions, that were practiced particularly by older (in the sense of: more skilful, experienced) women (old women, hag witches).

\section{Briefly about apotropaic birth in a caul}

Another fact linking shamans with some of our mythical beings and supernatural persons is birth in a caul; for example, as the future shaman is determined at birth among the Jurak-Samoyeds in Siberia. In other words, children who come into the world in a caul are predestined to become shamans, and those born with the caul covering the head only will become lesser shamans. ${ }^{112}$

Claude Lecouteux pointed out that ancient Scandinavian literature, because of the triad conception of the soul - fylgja, hamr and hugr (by which the ancient Scandinavians and the Germanic people termed that which Christians denoted with the concept of the soul) can help us in understanding the concept of ecstatic travel. If we examine briefly these concepts of the soul: fylgja, fylgjur (daimôn, genius) is a psychic, spiritual Double of an individual with a guardianship role, "one who follows, the female follower", who can leave a person during sleep and at the moment of death, while her dominant nature is animal. ${ }^{113}$ Hamr (hama in Old English) remains with the body as a physical double right up until the corpse is completely decomposed, and is thus, in this sense, related to the shamanistic soul of bones. ${ }^{114}$ Hugr (anima mundi, mana), as the third component of the soul in Scandinavian pneumatology, corresponds with the Latin concepts of animus and spiritus, and can also denote the Greek concept of nous, "faculty of thought, mind, intelligence", just as it figures as mens. ${ }^{115}$ The Early Norwegian verb fylgja - as Claude Lecouteux shows, writing out his register of the meanings of this term - means to follow, and also has the physiological meaning of the placenta - the membrane that follows the delivery of a newborn. ${ }^{116}$ Invoking Ginzburg's interpretation that hamr (one of the soul concepts in Scandinavian "pneumatology"), covering in Norwegian the meanings of "skin", "Double", and "caul", Claude Lecouteux, similarly to Ginzburg, established a profound link between

\footnotetext{
${ }^{109}$ Vukanović 1971: 174.

Cf. Marjanić 2002: 234-238 for some examples which testify to the cited coupling of the hearth - sorceresses' balm.

${ }^{110}$ Cf. IEF 1127: 18.

${ }^{111}$ Vukanović 1971: 188-189.

${ }^{112}$ Eliade 1974: 16 (cf. Ginzburg 2001: 123).

Eliade (1981: 108) reports that, according to popular beliefs in Romania, strigoi are born in a caul and, when they reach maturity, they put it on and become invisible. Lecouteux refers to the belief that persons who are born in a caul have second sight (Lecouteux 2003: 126).

${ }^{113}$ Cf. Raudvere 2002:98 on the animal and feminine fylgja.

${ }^{114}$ Lecouteux 2003: 45-47.

${ }^{115}$ ibid.: 49.

${ }^{116}$ ibid.: 68, 97.
} 
the caul - a portion of the foetal membrane (amnion, amnios) that certain babies have on their heads when they come into the world - and nocturnal flights. ${ }^{117}$

According to Croatian legends, moras and witches are born in a bloody/red caul (a red or black bladder), ${ }^{118}$ while krsniks (similarly to $z$ duhačs, for example) ${ }^{119}$ in an ethically white caul. ${ }^{120}$ Maja Bošković-Stulli mentions that the colour of the caul is irrelevant in certain regions, but that, particularly in Istria and neighbouring areas, because of polarisation into krsniks and strigons, the colour and type of caul are of utmost importance. ${ }^{121}$ For example, the red caul is entered into the embryological mythologem of the genesis of a mora and gynaecophobia has structured the belief on the ways in which a mora is born: a baby girl born in a red caul was fated and gynaecomorphologically predestined to become a mora. ${ }^{122}$ The genesis of a mora could be prevented if the bloody caul was destroyed immediately after birth - it was to be burnt or buried, which people were loath to do because it was believed that the caul was a human being's alter ego and so, the birth of a baby girl in a bloody caul was announced to everyone. ${ }^{123}$ The caul would be taken outside the house and the midwife would shout loudly that a little girl in a bloody caul had been born in that house; this was done to hinder the development of her demonic powers. ${ }^{124}$ If a baby girl was born in a white caul (in a normal birth,

${ }^{117}$ ibid.:95-96. It is worth noting here that individual interpretations ignore the difference between the placenta (posteljica) and the caul (košuljica). The caul, which is located under the decidua membrane, is wrapped around the foetus itself (Sučić 1943: 68). Still, Tihomir Đorđević also gave some synonyms for košuljica (caul) in individual Southern Slavic regions, including the lexeme posteljica (placenta) (Đorđević 1941: 89). Cf. Plotnikova 1999 and 2001: 291, Schneeweis 2005: 78, for positive and negative meanings attributed to being born in a caul, and also about its colour.

${ }^{118}$ Cf. Bošković-Stulli 1991: 149.

${ }^{119}$ Cf. Bošković-Stulli 1953: 336.

Zduhačs are found in legends from Bosnia and Herzegovina and Montenegro.

${ }^{120}$ For example, cf. the legend which speaks of how the štrigo is born in a black bladder, and the krsnik in a white caul (košulja) that is like a net, while a child born in such a caul has to wear it under its arm - the caul has to be sewn in under its armpit (Bošković-Stulli 1959:148, No. 157, Bošković-Stulli 2003: 14).

Bartulin described the krsnik's caul according to beliefs on Cres: they are born "wearing a thin net of milk like a shirt (a caul), which should be given to the child in some sort of soup so that it drinks it, they usually give it in coffee" (Bartulin 1898:267). Milčetić noted down that the skrstnik or krstnik (in Vrbnik and Spinčić) is born "under a small cap of skin. Theydryout this capand giveit to the child so that it eatsit with somefood"(Milčetić1896:225). Branko Fučić noted down a belief from the island of Cres that the krsnik is born "in a caul, a placenta, while the mrkodlak (is born) with 'a cap on its head, part of the amniotic sack (amnion)!", and, according to this belief, the krsnik must drink his caul, which gives him special powers (MS IEF 1142: 1, italics S.M.).

There is an interesting instruction in legends about the birth of krsniks, which says that the caul should be sewn in under the skin of the armpit, while the armpit topos also appears in oral poetry about the children/sons of dragons (zmajevita djeca), who are born with wings below their armpits (Zečević 1978:39). Cf. certain other legends about the birth of krsniks - according to Mikac 1934: 195, MS IEF 118: 55, Žiža 1913: 192, MS IEF 88:22,23, MS IEF 118: 54, Bošković-Stulli 2003: 28.

Cf. Marjanić 1999:60--2 on beliefs connected with the birth of moras in cauls.

${ }^{121}$ Bošković-Stulli 1975a: 219.

For example, in some beliefs its colour is not at all crucial in becoming a Hesperian creature: "If a female is born in a caul, she becomes a mora" (Milčetić 1896: 236).

${ }^{122}$ Cf. Marjanić 1999: 60-62.

${ }^{123}$ Zečević 1981: 146.

${ }^{124}$ MS IEF 1608: 17, No. 33.

According to beliefs on the islands of Brač and Hvar, a štriga (stringa) was born in a black caul so that it was necessary that the midwife (the baba) take the child out onto the house threshold as soon as it was born and call out three times: "A višćica (witch) has been born,/ But not a witch,/ Rather a real little girl", or: "A višćun (wizard) has been born,/ But not a wizard, rather a real young man" (Carić 1897: 710). 
a birth without difficulties, the uterine side of the afterbirth is a shining greyish-white in colour), it was believed that she would be fortunate: "(...) but I think in an ordinary caul, that's what they say, the one born like that is happier. But I don't believe that because I was born in one." 125 Namely, both the birth of a krsnik and mora, and strigons and strigas in Istria, like moras and witches in the Dalmatian regions, were loudly announced; Maja Bošković-Stulli identified the lack of logic in this practice, since it was believed that a krsnik could die or lose his powers if his identity was uncovered. This author concluded that the announcement of the krsnik's birth became customary analogously with that of the štrigon. ${ }^{126}$

Consequently, particular attention was paid if a child was born in a caul. In other words, in rare cases a child is born wrapped in the birth membrane - the caul; a child born in this way has less chances for survival, but if it does survive, that means that it is stronger than other children. In such cases, popular beliefs are grouped either around the birth in a caul or its colour, and in that way the mystic link between the caul and the child are revealed. ${ }^{127}$

\section{Axis mundi - the mythic geography of mountains and trees}

Folklore conceptions about the witches' and fairies' trees as their meeting places can be approximated to the concept of the World Tree as the topos of the soul. ${ }^{128} \mathrm{Mov}$ ing on to the following (possible) point of contact between witchcraft and shamanism, they are also linked by mythic geography - mountains and trees that figure as the axis mundi, the Centre of the World, ${ }^{129}$ while the customary witches' tree in Southern Slavic oral literary legends is the walnut-tree. ${ }^{130}$ In Konavle, however, witches gather in hollow olive-trees and underneath walnut-trees. ${ }^{131}$ Related to the trials of witches in Croatia, Ivan Tkalčić mentioned that witches gathered under oak trees, but rarely under linden trees. ${ }^{132}$ Josip Kotarski noted down a belief from Lobor that witches hold their covens at night on Good Friday, where they have a table in a spruce that has no crown. ${ }^{133}$ Mountains are designated as the gathering places of witches' power (the mountain peaks), in Eliade's definition cosmic peaks, and trees (arbor mundi), these being Earthly centresprotuberances (axis mundi) that establish contact between the celestial and the terrestrial world. ${ }^{134}$ The cited mythic geography has been preserved in the witches' magical verbal formulae (the verbal symbol of the ritual) that witches utter after they have

\footnotetext{
${ }^{125}$ MS IEF 1608:17, No. 33.

${ }^{126}$ Bošković-Stulli 1975a: 219.

${ }^{127}$ Trebješanin 2000:85, 87.

${ }^{128}$ Veleckaja 1996: 36-37, cf. Marjanić 2004a: 233-239 on the concept of the World Tree as a topos of the soul.

${ }^{129}$ Eliade 1974: 12-127, 269-274, 477-482, cf. Čiča 2002: 89-90.

${ }^{130}$ Zečević 1981: 141, cf. Marjanić 2002: 235.

Establishing that ecstatic ascent into the Heavens was often replaced ritually by symbolically climbing up into a tree, and Zoran Čiča came to the conclusion that fairies in the world of legends were usually located under the following fairies' trees - the oak, elm, pear, and hawthorn or under a holly tree (zapis) (Čiča 2002: 89-90, 95), while Dušan Bandić mentioned that the oak, elm, pear, hawthorn, mulberry, and holly tree (zapis) figure as fairy trees (Bandić 1980: 244-245).

${ }^{131}$ Bogdan-Bijelić 1907: 307.

132Tkalčić 1891: 25.

${ }^{133}$ Kotarski 1918: 50.

${ }^{134}$ Eliade 1974: 266-269.
} 
rubbed themselves with balm, which is the concluding magical act through which they achieve astral navigation: "To Biokovo under the walnut tree"; 135 "- Not of wood nor of stone, but to Muć under the walnut tree", ${ }^{136}$ or, as this formula is uttered on the island of Brač: "Not of wood nor of stone,/ But into the field (polje) under the walnut tree."137 Apart from these mythic oronyms, there is also mention, of course, of Medvednica/ Sljeme, ${ }^{138}$ Klek, ${ }^{139}$ Aršanj (probably Harsány Mountain in Hungary) and Pulja. ${ }^{140}$ And while Maja Bošković-Stulli deciphers the toponym Pulja as Puglia in southern Italy, Slobodan Zečević defines it as Pula (the coastal town of Pula) due to the legendary walnut tree, but according to Carić's notation, as the above-mentioned example shows, what is in question is a field (polje). Pulja usually appears as a zoopsychonavigational topos for witches in Dalmatia, ${ }^{141}$ on the island of Lastovo, for example, where a belief existed that witches came together on the eve of the saints' days of St John and St Peter and went to a walnut tree on Pulja; "they come together there and later return and do damage". In the same way, when jumping over the holiday bonfires, the verbal symbol of the ritual was incanted: "'In the name of God and St John (or Peter) let the witches burn wherever they be!' or 'In the name of God and St Peter may the witches' manda burn!' (Manda is a coarse expression meaning female genitals, and there is also the expression 'You manda!' with the aforesaid meaning)."142 We can find this explanation in another legend, also from Lastovo, in which the collocutor, Petar Lešić (son of Pavle) (born 1916) says: "When jumping over the fire, one speaks. Women there, when they jump over the fire, usually don't wear any panties. And then they say: - In the name of God and St Peter, may it burn up among the witches... hop! - over the fire."143 Or, in the modified version on the island of Korčula: "In the name of the Father and St Vid, may the witches' 'cunts' burn up!". ${ }^{144}$

Eliade underscored that the ecstatic journey of shamans always takes place near to the Axis/Centre (the World Tree), which evokes a three-storied cosmology - the Earth with the Celestial World above and the Netherworld below, and how the Buryats call the shamanistic birch "the Guardian of the Door" (udeši-burkhan), since it opens the

\footnotetext{
${ }^{135}$ Bošković-Stulli 1967-1968: 405, No. 8.

${ }^{136}$ Bošković-Stulli 1993: 293-294, No. 175.

${ }^{137}$ Carić 1897: 711, italics S.M.

Cf. Đorđević 1953: 33-34 for witch psychonavigational formulae.

${ }^{138}$ Zečević 1995: 79, 96.

${ }^{139}$ Bayer 1982:242, 572.

${ }^{140}$ About Pulja, cf. for example, the legend according to Marks 1980: 267, No. 52.

Antun Pavić noted that fairies frequently gather on hills such as Papuk and Brizovo Polje, but largely on Haršanj that is located in the middle of the Baranja region (Pavić 1852: 342).

Cf. the legend containing the witch psychonavigational formula "Not on a log nor on a stump, but straight to Aršanj" according to Bošković-Stulli 1963:293-295, No. 149. Cf. Jardas's notation on štrigas (witches) in the Kastav region (Jardas 1957: 102).

${ }^{141}$ Cf. Bošković-Stulli 1991: 135, Zečević 1981: 142.

For example, Marijan Livijo noted down the belief from Veli Iž (a settlement on the Island of Iž) that "they used to come to Pula or even further, as far as Africa. They could also come in a cloud and cause thunder, hail, rain and storms" (MS IEF 1195: 4). In addition to the mentioned Pula form, M. Livijo also noted the form Pulja (ibid.: 6). Kadčić did not define Pulja geographically, but only wrote:"Because there were so many walnut trees, and large ones at that, in Pulja. Witches often go there" (Kadčić 1859: 332).

${ }^{142}$ MS IEF 959: 20-21.

${ }^{143}$ MS IEF 1218: 69, No. 50.

${ }^{144}$ MS IEF 783: 11.
} 
entry to the Heavens ${ }^{145}$ for the shaman. The shamanist birch in Altaic shamanism symbolises the World Tree, which is located in the centre of the universe, the cosmic axis that connects the Sky, the Earth and the Netherworld, while the seven, nine or twelve notches (tapty) represent the Heavens, the celestial planes. ${ }^{146}$

Due to the permeation between witch and shaman cosmology in the context of the axis mundi mythem, ${ }^{147}$ it is obvious that this type of cosmology is not limited to the shamanist context. Thus, this reveals another link, as Zoran Čiča demonstrated in his book The Vilenica and the Vilenjak: the Destiny of a Pre-Christian Cult in the Period of Witch Persecution (2002), showing the link between the vilenica and shamanistic phenomenology, while pointing out that this does not also suggest the shamanistic character of the phenomenon in the narrow sense. ${ }^{148}$ The author carries through an extremely interesting comparison in observation of the ecstatic cult of vilenica and vilenjak in the context of Euro-Asian shamanistic practice, examining, for instance, the shamanistic ecstasy technique (astral journeying) and the mythic geography of mountains and trees (os sacrum) in the initiation of the vilenica (ascensus to a tree as the venue of the initiation process, ecstasy, and establishing a relationship with spiritual/astral beings) and the vilenjak (for example, ecstatic ascensus to a mountain, conferring power).

In Siberian shamanistic mythology, the axis mundi figures largely as a white birch (Betula alba) that is planted in the centre of the round yurt (tent) during the shaman initiation ceremonies and reaches up to the opening in the top of the tent, which represents the Door of Heaven or the Sun, through which the shamans depart from the Cosmos into the Axis of the Polar Star. ${ }^{149}$ In this connection, Zmago Šmitek mentioned that fairytales with the motif of climbing into a tree are definitely connected with the concept of the EuroAsian shamanistic tree and/or with the concept of the World Tree (os sacrum), which is also known among the Indo-Europeans. ${ }^{150}$ Otherwise, the shamans' drums are made from the bark of the World Tree, and from its trunk or branches. ${ }^{151}$

\section{Hallucinogens and psychonavigation}

Researching the role of hallucinogens in European witchcraft and in shamanism, Michael J. Harner concluded that these two magical practices were mutually linked with psychotropic drugs, and that they largely used plants from the order Solanaceae (the potato family) - thorn apple (Datura), mandrake, henbane (Hyoscyamus), and Deadly Nightshade or belladonna. ${ }^{152}$ For example, the latter (L. Atropa belladonna), was processed together with other ingredients from other plants from the Solanaceae order for the so-called magical balm, which was rubbed in to the mucous membrane around the

\footnotetext{
${ }^{145}$ Eliade 1974: 194.

${ }^{146}$ ibid.

L.L. Abaeva did research on the role of the tree cult among the Mongol peoples (the Mongols, Kalmics, and Buryats), charting the transformation of the World Tree - World Mountain concept of the archaic world-view into the shaman's tree and, finally, into the shaman's stick (cf. Hoppál 1993a: 278).

${ }^{147}$ Cf. Čiča 2002: 90.

${ }^{148}$ ibid.: 86-87.

${ }^{149}$ Chevalier, Gheerbrant 1987: 62.

${ }^{150}$ Šmitek 1999: 184.

${ }^{151}$ Cf. Bowker 1998:181, Vitebsky 1995: 81.

${ }^{152}$ Harner 1976: 128.
} 
genitals, on the forehead and under the arms in order to attain a feeling of intoxication. ${ }^{153}$ Thomas S. Szasz mentioned the fact that sorceresses had once been called Good Women or Lovely Lady - Bella Dona, thus, by the name of their remedy that is still used today in pharmacopoeia. ${ }^{154}$ Apart from these psychoactive plants, hemlock and aconite/monkshood, which also contain powerful psychoactive alkaloids, ${ }^{155}$ were used as well. The folklorist Will-Erich Peuckert explained in his interpretation of the broom that the cited psychonavigational vehicle was used as an applicator for lubricating the sensitive vaginal membrane with hallucinogens that contained atropine, which induced the feeling of flying. ${ }^{156}$ Consequently, in addition to rubbing their bodies with ointment, and rubbing it into their skin, which made possible its absorption into the bloodstream, they also used it on their vehicles - brooms, spindles, sticks, benches... ${ }^{157}$ According to one particular Mediaeval recipe, Peuckert mixed a witch balm from thorn apple, henbane and Deadly Nightshade, which he rubbed into his armpits and onto his forehead. He described the twenty-four-hour-long state of intoxication and deep sleep with images: "wild hellish riding, intoxication with love, fantastic flights into eternity, and a fort surround by disfigured, grotesque creatures". ${ }^{158}$ The witches' balm in the worlds of Southern Slavic legends, as well as in the theological instrumentary, was sometimes diabolised. Namely, according to Southern Slavic legends, it was believed that the witch brewed her balm by cooking the outcome of her coupling with the Devil, and by boiling up human blood and fat... It was also believed that the ointment was made of nail cuttings, the remnants of the foreskin removed in the circumcision of male children, and from pubic hair. ${ }^{159}$

Harner underscored the fact that he does not claim that hallucinogenic plants were used in all shamanistic practices, ${ }^{160}$ while, in Eliade's opinion, the use of narcotics as an ecstatic stimulant represents a vulgarisation of shaman tradition: "(...) the use of narcotics is, rather, indicative of the decadence of an ecstasy technique or of its extension to 'lower' peoples or social groups" and that the use of narcotics (tobacco...) is a relatively new phenomenon in the far North-East. ${ }^{161}$ I would remind readers that Gordon R. Wasson in his study Divine Mushroom of Immortality (1968) examined the

\footnotetext{
${ }^{153}$ Schaffner 1999: 49.

Deadly Nightshade (variously known as luda trava, vučja trešnja, norica, L. Atropa belladonna), one of the most poisonous plants found in the South-Slavic regions: "When someone is deceived and eats its sweetish berries, then, according to what witnesses say, that person formally becomes insane, walking as if he/she has gone amok and talking all kinds of nonsense. When more of those berries are eaten, then they cause a type of rabies with hallucinations, paralysis, unconsciousness and uncontrolled body movements. Then the people say: 'he blundered into a witches' dance' (vrzino kolo), or 'he suddenly went mad'" (Kazimirović 1986: 174).

${ }^{154}$ Szasz 1982: 101.

${ }^{155}$ Plant 2004: 104.

${ }^{156}$ According to Petersdorff 2001: 162, cf. Plant 2004: 105.

${ }^{157}$ Hruškovec 1998: 31-32.

${ }^{158}$ According to Petersdorff 2001: 162.

${ }^{159} \mathrm{Cf}$. Zečević 1981: 141. For several examples of Croatian oral literary legends which have witches' balm as their theme, cf. Marjanić 2002. For example, Johannes Hartlieb (Das Buch aller verbotenen Künste, des Aberglaubens und der Zauberei, 1456) even gives the name of the witches' psychonavigational ointment (ugentum Pharelis) (cf. Bayer 1982: 357). Following Hartlieb, Lecouteux writes the name of the balm as unguentum Pharelis (Lecouteux 2003:84).

${ }^{160}$ Harner 1976: XV.

${ }^{161}$ Eliade 1974: 477, cf. McKenna, McKenna 1994: 15.
} 
essential role of the Amanita muscaria mushroom in Siberian shamanism. ${ }^{162}$ Elio Schaechter pointed out that this mushroom, whose pileus is red on top with white scaling, is found in children's picture-books and that it not only hallucinogenic but also toxic. ${ }^{163} \mathrm{In}$ an ironic tone, Sadie Plant added that one of the most permanent embodiments of the archaic shamanistic journeys visits the world once a year as Santa Claus who, dressed in red and white, flies through the expanses of the heavens in a sleigh pulled along by reindeer and brings gifts from the other world. ${ }^{164}$ Shamans of the northern Asian regions consume the Toadstool, the Amanita muscaria, which is often found beside the roots of the birch or the fir tree - thus, those very trees that they use as the axis mundi. ${ }^{165}$ Some hold the opinion that it is that mushroom - which was infamous in the past and was called the mushroom of the insane and the throne of toads (or T/toadstool) - which could be the puzzling plant used in making soma according to the Vedic hymns and/or the haoma according to the Iranian Avesta. The ethnomycologist Wasson mentions that the description of soma in the Rigveda as breasts splattered with milk corresponds with the description of the Amanita muscaria. ${ }^{166}$

Let us look at another frequent motif concerning moras' and witches' psychonavigations. For example, it was said in Luka on the Island of Dugi Otok that the štrigas (witches) arrived by boat from Italy, and, when it drew near to Luka, the boat would transform into an egg-shell and the oars into bird feathers, while legends have also been noted down about štrigas travelling in an egg-shell. ${ }^{167}$ Another belief from Veli Iž (a settlement on the Island of Iž) speaks of štrigas who travelled "in an egg-shell and rowed with matches for oars with

${ }^{162}$ Cf. McKenna, McKenna 1994: 15, Plant 2004: 106.

M. Hoppál mentions that the mushroom Amanita muscaria (fly agaric, mad mushroom) is used in witchcraft and not only in shamanism, when love-inducing magic potions are in question. He adds that milk serves as a powerful detoxicant to counteract the impact of fly agaric, which could be linked with the legend that speaks of the witches stealing milk in village communities (Hoppál 1992: 159). Cf. examples of fantastic descriptions of witches stealing milk according to Bošković-Stulli 1991: 129. This author points out that spoiling and taking milk from other peoples' cows was a typical injurious procedure that was transposed from popular magic into the theological concept of witchcraft, and was preserved in folk beliefs right up to very recent times (ibid.), while, for example, certain theological conceptions, particularly those about witches' meetings, transposed from learned to oral tradition (ibid.: 126). In Kompolje it was believed that witches' ointment was, in fact, butter made from stolen milk, while particularly good butter was that made by witches who "melted it down from milk stolen from women who were nursing babies" (Grčević 2000: 503). For example, I. Tkalčić wrote in relation to trials of witches in Croatia that, according to the cited "testimonies", witches like to take the milk of other peoples' cows on farms (Tkalčić 1891: 7). Writing about Brest, J. Mikac mentioned that, according to beliefs, štrigas could take a cow's milk "in such a way that they would throw an opta (a yarn rope) over the cow's back and milk her into a sieve, while the milk from the sieve would go to the štriga's house" (Mikac 1934: 199). For example, V. Fortunić wrote about the mushroom called vještičine rigotine (witches' vomit) by the people as being "whitish-red, in the shape of a dome (...). It is said that witches gather in that hole because there are such mushrooms there (the ones called witches' vomit by the people)" (MS. IEF 192: 12).

${ }^{163}$ Schaechter 1998: 190.

${ }^{164}$ Plant 2004: 107.

Or, we can recall the Smurfs, those small blue creatures with white caps (only Papa Smurf has a red cap), who live in houses made of mushrooms, and possess magic powers.

${ }^{165}$ Chevalier, Gheerbrant 1987: 62.

Ginzburg added that, apart from the Altaics, the Siberian peoples used the toadstool, while the practice in question was implemented especially by the shamans in achieving ecstasy (Ginzburg 1991: 305).

${ }^{166}$ Visković 2001: 365, 489.

${ }^{167}$ Lulić 1993: 364. 
a stroke covering one hundred miles". ${ }^{168}$ Another belief was: that "witches and moras could cross the sea in only an egg-shell", ${ }^{169}$ while an apotropaic defence from the nyctomorphic activities was that the victim of their attack could escape, because the Hesperian beings in question could not cross the sea - other than in an egg-shell. The imaginary Lilliputian image and dreams about moras and witches floating on the sea in a walnut- or egg-shell ${ }^{170}$ are psychosymbols of Gulliver-type searches for enclosure in one's own shell (room) from fear of night as the time of dark thoughts ${ }^{171}$ and miniature moras (Tom Thumb creatures) in their animalistic Hesperian activities. Sadie Plant drew attention to the fact that one of the best known effects of the Amanita muscaria is a feeling that one is growing or reducing in size, which has a key role, for example, in Carroll's Alice in Wonderland while - as is known - Lewis Carroll had access to several studies on the Amanita muscaria mushroom, and probably to the mushroom itself. ${ }^{172}$

Let us pause for a moment at an apotropaic against the negative activities of moras and witches. ${ }^{173}$ Namely, in addition to the broom turned upside-down behind the door as an apotropaic against witches and moras, other objects such as fine and coarse sieves can also serve this purpose, because they have so many holes, "while the popular belief is that witches and moras cannot move forward, cannot do anything or inflict any harm, before they count all the holes on the fine and coarse sieves". The sieve is also part of the witches' instrumentary as well as being an attribute of moras who like to ride in them through the air: "This conception was arrived at through the fact that somebody saw similarity between a storm cloud and the shape of a sieve, which lets water pass through; in a similar way, a storm cloud was conceived as a broom, that sweeps everything before it; and the derivation from that was that witches on brooms rode in the clouds or that they ride in a sieve through the air." 174 Perhaps the fairytale elements of the journeys of moras and witches in walnut-shells or egg-shells and in sieves could also be linked with shamanistic journeys. Namely, Mihály Hoppál mentions the fact that, in the Hungarian belief system, some very characteristic features of shamanism were preserved in the form of the drum=sieve=boat equation, while he commences this parallelism with an indication of how the Hungarian shaman, the táltos, is linked with the sieve (coarse sieve). ${ }^{175}$

Consequently, in the (possible) comparisons between witchcraft and shamanism given above, I stress the point that we are speaking only of possible points of contact, since Gustav Henningsen has emphasised that shamanism is not appropriate for explaining witchcraft as these are, in fact, diverse ecstatic cults and variations of lethargy. ${ }^{176}$

\footnotetext{
${ }^{168}$ MS IEF 1195: 4, 5.

${ }^{169}$ Milčetić 1896: 286.

${ }^{170}$ Bošković-Stulli 1959: 220.

${ }^{171}$ Cf. Durand 1991: 221.

172 Plant 2004: 107.

${ }^{173}$ I wrote in more detail about apotropaics against mora activities in the text "Apotropaics Against the Mora as a Female-Nyctomorphic Demon" (1999).

${ }^{174}$ Stojković 1929: 51-53.

${ }^{175}$ Hoppál 1992: 164.

Cf. the earlier quoted part of the legend according to Mikac 1934:199 where the link was established in the folklore imaginary about witches stealing milk with the aid of a sieve.

${ }^{176}$ Henningsen 1991/1992: 301-302. Cf. systematisation of the inducing of shamanistic altered states of consciousness according to Hoppál 1993: 185.
} 
Something should be added here about the terms trance and ecstasy. For example, Merete Demant Jakobsen points out that the terms trance and ecstasy are used indiscriminately and that Louise Bäckman and Åke Hultkranz claims that the term ecstasy is being used by students of religion and ethnology, while the term trance is being used by psychopathologists and parapsychologists. ${ }^{177}$ Still, Dragoslav Antonijević, follows Gilbert Rouget's distinction between ecstasy and trance, emphasising that the use of trance indicates movement, noise, society, crisis, sensory over-stimulation, and amnesia, with the exclusion of hallucinations; in ecstasy - it is a matter of immobility, silence, the absence of crisis states and sensory over-stimulation, and hallucinations, which means that witch psychonavigation would have the characteristics of ecstasy, while their nyctomorphic gatherings (the ritual covens) would indicate the structure of trance. ${ }^{178}$

Still, it is not, unfortunately, possible to establish the parallelism between the $a b$ stract figures of the shaman and the witch on the level of the shaman's role as a healer. Namely, Croatian legends very rarely indicate healer practice among witches. However, let us look at one case that reveals a witch also in that role. For example, writing about Praputnik, J. Bujanović noted that one witch (whom we will denote as being ethically white) fended off the evil spells of an (ethically black) witch: "He was healed by another witch with the aid of prayers, and he had to jump over a hoe, an axe, a rake, a shovel, and some boards and other things, into which the witch blew and prayed over them, crossing herself."179

\section{Briefly and in conclusion: the translation of shamanism and witchcraft in art, politics, and cultural tourism...}

I would close the case of transference of shamanistic patterns into other spheres today with the example of shamanism in art - in music as technoshamanism ${ }^{180}$ and, of course, in the fine arts, in expressive painting, and in performance art. ${ }^{181}$ For example, Joseph Beuys incorporated the shamanism dimension into both his life story and his artistic work, and, later, he expanded the shaman role into his own role as political leader, ecology activist and spiritual-artistic educator. ${ }^{182}$ Namely, he flew in the Crimea war zone as a member of the German army during World War II and was shot down there in 1943 by Soviet artillery. Tartars found him in the wreck of his Junkers 87 and restored him to health, while the encounter with Tartar shamanistic culture became an initial element in his works. During the healing process, the Tartar shamans rubbed fat over his body and wrapped him in felt, and Beuys remained permanently dedicated in his works to the felt

\footnotetext{
${ }^{177}$ Jakobsen 1999: 17; cf. ibid.: 10.

${ }^{178}$ Antonijević 1990: 9.

${ }^{179}$ Bujanović 1896: 234.

${ }^{180}$ This term was coined by Frazer Clark in 1987, describing the role of the DJ at a rave (cf. Harvey 2003a: 305).

${ }^{181}$ I shall not, unfortunately, be going into detail about this transgression of shamanism, but would recommend Robert J. Wallis's excellent book Shamans/Neo-Shamans, which researches the transition of shamanism from its autochthonic context to Western contextualisation from the 1960s, which is all part of the globalisation process (Wallis 2003:58), revealing how the processes of democratisation, and the spread of capitalism and Western values have also had an influence on shamanism, "but it would be naïve to contrast traditional- and neo-Shamanism in terms of the West doing all the transformation" (ibid.: 207).

${ }^{182}$ Cf. Šuvaković 1999: 336.
} 
and fat elements of the shaman process. ${ }^{183}$ For example, in the shaman action Coyote: $I$ Like America and America Likes Me (1974) he tried to establish contact with the mythical animal of the Native Americans - the coyote - as a symbolisation of the America that had disappeared during the settlers' expansion to the West. A Texas coyote named Little John took part in the cited action; Beuys spent four days with him (May 23 to 26) in the René Block Gallery in New York, trying to establish mutual alteration of Nature. His daily rituals included a series of interactions with the coyote, for example, he spoke with the coyote, ${ }^{184}$ acquainted him with objects - felt, a walking stick, gloves, an electric torch and the Wall Street Journal, a symbol of the American God Mammon (the paper was delivered every day), while Little John tore at it with his feet and urinated on it. Namely, the floor was covered in straw and then, during the exhibition, with copies of the Wall Street Journal. ${ }^{185}$ According to Beuys, the Coyote was an "American" action, the "coyote complex", which reflected the history of the persecution of the Native Americans as well as "the whole relationship between the United States and Europe". ${ }^{186}$ During the action, Beuys produced primary/archaic sounds and minimal music; he also fell to the floor as if in a trance. He imitated neophyte procedures that Mircea Eliade had described in his study about shaman ecstasy techniques. ${ }^{187}$ The study is about the procedure among the Schuswap, a tribe of the Salish family in the interior of British Columbia. The aforementioned shamanistic initiation sometimes lasts for years, until the novice dreams "that the animal he desired for his guardian spirit appeared to him and promised him its help. As soon as it appeared the novice fell down in a swoon:

(...) If an animal initiates the novice it teaches him his language. One shaman in Nicola Valley is said to speak 'coyote language' in his incantations." ${ }^{188}$

The director of the Ogulin Tourist Board, Ankica Puškarić, made an excellent translation with her colleagues of legends about witchcraft, and founded a festival called The Festival of Witches and Fairies. So, for those who would like to participate in some merry casting of spells - the First Festival of Witches and Fairies was held on Friday, June 13, 2003 on Klek Mountain, and the three main conditions for joining the Witches' Sisterhood were - a cheerful nature, your own birch broom, and a licence for riding on the aid in question. ${ }^{189}$ Instead of actual psychonavigation, of course, the Klek sorceresses competed

\footnotetext{
${ }^{183}$ Borer 2003: 285.

${ }^{184}$ Davvetas 2003: 173.

${ }^{185}$ Lamarche-Vadel 2003: 121.

${ }^{186}$ Cf. Goldberg 2001: 151.

${ }^{187} \mathrm{Cf}$. Jacobs http.

${ }^{188}$ Eliade 1974: 100.
}

For example, shamanism in contemporary Croatian visual arts practice is noticeable in the work of Vladimir Dodig Trokut (cf. 2002), Josip Zanki, Marijan Crtalić (cf. 2004), Damir Stojnić (cf. 2006). Cf. the critical interpretations of using the coyote Little John in Beuys's action I Like America and America Likes Me according to Steve Baker (2003) and Damir Stojnić (2006). The aforementioned artist Krešimira Gojanović (cf. note No. 20), for example, gave a dance performance art as part of the multimedia project Teatar i mit (Theatre and Myth) at the Gavella Theatre (Zagreb) in 2000 (the project was conceived and produced by: Bojan Gagić and Josip Zanki). The theme of the performance art was natural femininity (points of contact between Nature and female feelings) and a return to white witchcraft (Wicca) in touch with the forces/energies of Nature.

${ }^{189}$ In my opinion, since the contemporary Wicca are drawn near to the ecofeministic, and thus, the animalistic paradigm, the organisers of this manifestation could perhaps have avoided the elements in which the 
with each other in a witches' alka (a ring-tilting game), a witches' races with pedalos, witches' beach volleyball, witches' balot (Mediterranean bowls), soccer, and belotte (a card game)... ${ }^{190}$

The fact that shamanism is also applicable to the political powers-that-be was testified to in the recent case in which a shaman applied to carry out the ritual purification of the Russian State Duma (parliament) building and to drive out the evil spirits drawn to it by the negative energy of political debates. Namely, the Government allegedly hired him to come from Siberia for that purpose. The shaman and mystic, Toizin Bergenov, announced that he would come to Moscow in June when "the spirit of the Sun is exceptionally powerful". The building was last purified in 1994, when it was decontaminated by representatives of the Russian Orthodox Church. ${ }^{191}$

\section{References cited}

Antonijević, Dragoslav (1990): Ritualni trans. SANU, Beograd.

Ardalić, Vladimir (1917): Vile i vještice (Bukovica u Dalmaciji). Zbornik za narodni život i običaje Južnih Slavena, 22:302-311, Zagreb.

Baker, Steve. 2003. "Sloughing the Human". In: ed. Cary Wolfe, Zooontologies: The Question of the Animal, 146-164.

Bandić, Dušan (1980): Tabu u tradicionalnoj kulturi Srba. BIGZ, Beograd.

Bartulin, Andrija (1898): Cres. Vjerovanja. Zbornik za narodni život i običaje Južnih Slavena, 3:[Ljudi po smrti, str. 267-269], Zagreb.

Bayer, Vladimir (1982): Ugovor s đavlom. Procesi protiv čarobnjaka u Evropi a napose u Hrvatskoj. Informator, Zagreb.

Belaj, Vitomir (1998): Hod kroz godinu. Mitska pozadina hrvatskih narodnih običaja $i$ vjerovanja. Golden marketing, Zagreb.

Bogdan-Bijelić, Paulina pl. (1907): Vještice (Konavle u Dalmaciji). Zbornik za narodni život i običaje Južnih Slavena, 13/2: 306-308, Zagreb.

Borer, Alain (2003): "Jadikovka za Josephom Beuysom". In: ed. Ješa Denegri, Dossier Beuys, DAF, Zagreb, 281-324.

Bošković-Stulli, Maja (1953): Splet naših praznovjerja oko vještice i popa. Bilten Instituta za proučavanje folklora, 2: 327-342, Sarajevo.

Bošković-Stulli, Maja (1959): Istarske narodne priče (Redakcija, uvod i komentari). Institut za narodnu umjetnost, Zagreb.

excursionists - the fairies and witches at the First Festival of Witches and Fairies came down Klek Mountain to Bjelski, where they toured around the hunting grounds of Gama and Croatian Forests, and where "their hosts had prepared them a large pot of game goulash" (Ogulinski list, 87, June 2003; www.og-list. com/broj87.htm).

${ }^{190} \mathrm{Cf}$. the photographs from the Festival held from June 17-19, 2005. (http://www.ogulin.hr/index.php?subact ion=showfull\&id=1119122452\&archive $=\&$ start_from $=\& u$ cat $=\&)$. The local Tourist Board drew its inspiration for the Festival from the legends about Klek Mountain witches, which were written down by Janez Vajkard Valvasor (Slava vojvodine Kranjske, 1689). According to Valvasor, witches, mountain fairies (vile planinkinje) and vilenjaks from all over the world gather on the very peak of Klek at midnight on stormy nights, and their wild kolo (circle-dance) and screams can be heard as far away as Ogulin (cf. Klečke vještice http.).

${ }^{191}$ Fišić 2004: 64. 
Bošković-Stulli, Maja (1962): Pomorska tematika u našoj narodnoj književnosti. Pomorski zbornik. Povodom 20-godišnjice Dana mornarice i pomorstva Jugoslavije, 19421962. I, JAZU, Zadar, 505-536.

Bošković-Stulli, Maja (1963): Narodne pripovijetke. Pet stoljeća hrvatske književnosti, knj. 26, Zora - Matica hrvatska, Zagreb.

Bošković-Stulli, Maja (1967-1968): Narodne pripovijetke i predaje Sinjske krajine. Narodna umjetnost, 5-6: 303-432, Zagreb.

Bošković-Stulli, Maja (1975): Usmene pripovijetke i predaje s otoka Brača. Narodna umjetnost, 11-12: 5-159, Zagreb.

Bošković-Stulli, Maja (1975a): Usmena književnost kao umjetnost riječi. Mladost, Zagreb.

Bošković-Stulli, Maja (1991): Pjesme, priče, fantastika. Nakladni zavod Matice hrvatske - Zavod za istraživanje folklora, Zagreb.

Bošković-Stulli, Maja (1993): Žito posred mora: usmene priče iz Dalmacije. Književni krug, Split.

Bošković-Stulli, Maja (1997): Priče i pričanje: stoljeća usmene hrvatske proze. MH, Zagreb.

Bošković-Stulli, Maja - Ljiljana Marks. 2002. "Usmene priče iz Župe i Rijeke dubrovačke". In: eds. Dunja Fališevac, Josip Lisac, Darko Novaković, Književna baština, Ex Libirs, Zagreb, 441-427.

Bošković-Stulli, Maja (2003): "On The Track of Kresnik and Benandante". In: MESS. Vol. 5, Mediterranean Ethnological Summer School, Piran, Pirano, Slovenia 2001 and 2002/ edited by Rajko Muršič in Irena Webre. Ljubljana: Filozofska fakulteta, Oddelek za etnologijo in kulturno antropologijo, 13-40.

Bowker, John (1998): Religije svijeta. Znanje, Zagreb.

Broomstick History (http://www.magickdragon.net/Bromm.html).

Buchholz, Elke Linda (1999): Francisco de Goya. Life and Work. Könemann, Köln.

Budimir, Milan (1966): Vampirizam u evropskoj književnosti. Anali Filološkog fakulteta, VI:269-273, Beograd.

Bujanović, J. (1896): "Praputnik". Zbornik za narodni život i običaje Južnih Slavena, I: 226, Zagreb.

Carić, Antun Ilija (1897): Narodno vjerovanje u Dalmaciji. - Štrige, ili štringe na ostrvima Braču i Hvaru. Glasnik Zemaljskog muzeja u Bosni i Hercegovini, IX: 710-713, Sarajevo.

Chevalier, Jean - Gheerbrant, Alain (1987): Rječnik simbola. Mitovi, sni, običaji, geste, oblici, likovi, boje, brojevi. Nakladni zavod $\mathrm{MH}$, Zagreb.

Chloupek, Drago (1953): Mogut. Zbornik za narodni život i običaje Južnih Slavena, 37: 241-250, Zagreb.

Crtalić, Marijan (2004): Kad kustoski "materijal" progovori o davljenju. In: Zarez: dvotjednik za kulturna i društvena zbivanja, 124, 26 February 2004, Zagreb, 34-35.

Čiča, Zoran (2002): Vilenica i vilenjak. Sudbina jednoga pretkršćanskog kulta u doba progona vještica. Institut za etnologiju i folkloristiku, Zagreb.

Davis, Noah (2001): Harry Potter Rides Broom Incorrectly. (http://www.hollywood.com/ news/detail/article/471205).

Davvetas, Demostenes (2003): Joseph Beuys - čovjek je skulptura. In: ed. Ješa Denegri, Dossier Beuys, DAF, Zagreb, 161-184. 
Deželić, Gj. Stjepan (1983): Odgovor na pitanja, stavljena po historičkom družtvu. Od Gjurgja Stjepana Deželića. Arkiv za povjestnicu jugoslavensku, Knjiga VII: 199232, Zagreb.

Dodig Trokut, Vladimir (2002): Mistički poligoni \& akcije-inicijacije. In:Zarez: dvotjednik za kulturna i društvena zbivanja, 94-95, 17 December 2002, Zagreb, 42-43.

Dowson, Thomas A. - Martin PORR (2001): Special Objects - Special Creatures: Shamanistic Imagery and the Aurignacian Art of South-East Germany. In: ed. Neil S. Price, The Archaeology of Shamanism, Routledge, London and New York, 165177.

Durand, Gilbert (1991): Antropološke strukture imaginarnog. Uvod u opću arhetipologiju. August Cesarec, Zagreb.

Đorđević, Tihomir (1941): Deca u verovanjima i običajima našega naroda. Beograd: Biblioteka Centralnog higijenskog zavoda.

Đorđević, Tihomir (1953): Vampir i druga bića u našem narodnom verovanju i predanju. Srpski etnografski zbornik, LXVI, Beograd.

Eliade, Mircea (1981): Okultizam, magija i pomodne kulture: eseji s područja komparativne religije. GZH, Zagreb.

Eliade, Mircea (1983): Kovači i alkemičari. GZH, Zagreb.

Eliade, Mircea (1985): Šamanizam i arhajske tehnike ekstaze. Matica srpska, Novi Sad.

Fišić, N. I. (2004): Šaman čisti ruski parlament od zlih duhova. Jutarnji list, 11 May 2004 (No. 2151), 64, Zagreb.

Ginzburg, Carlo (1991/1989): Ecstasies: Deciphering the Witches' Sabbath. Penguin Books, London.

Ginzburg, Carlo (2001): Deciphering the Witches' Sabbat. In: ed. Darren Oldridge, The Witchcraft Reader, Routledge, London - New York, 120-128.

Goldberg, RoseLee (2001/1979): Performance Arts: From Futurism to the Present. Thames \& Hudson, London.

Graves, Robert - Raphael Patai (1969): Hebrejski mitovi. Knjiga postanka. Naprijed, Zagreb.

Gray, Leslie. Shamanism and Eco-Psychology. (http://www.wellnessgoods.com/shamanismecopsych.asp).

Gray, Leslie. 1995. "Shamanic Counseling and Ecopsychology". In: ed. Theodor Roszak, Ecopsychology: Restoring the Earth, Healing the Mind. Sierra Club Books, San Francisco, 172-182.

Grčević, Jure (2000): Kompolje: narodni život i običaji. Katedra Čakavskog sabora pokrajine Gacke, Otočac.

Gura, A. V. (1997): Simvolika životnych v slavjanskoj narodnoj tradicii. Izdatel'stvo "Indrik", Moskva.

Gwydion (1994): Vika - drevna religija veštica. Esotheria, Beograd.

Harner, Michael J. (1976): The Role of Hallucinogenic Plants in European Witchcraft. In: ed. Michael J. Harner, Hallucinogens and Shamanism, Oxford University Press, London - Oxford - New York, 126-149.

Harner, Michael J. (1976a): Introduction. In: ed. Michael J. Harner, Hallucinogens and Shamanism, Oxford University Press, London - Oxford - New York, XI-XV.

Harvey, Graham (2003): General Introduction. In: ed. Graham Harvey, Shamanism: A Reader, Routledge, Taylor \& Francis Group, London - New York, 1-23. 
Harvey, Graham (2003a): Introduction to Part Five. In: ed. Graham Harvey, Shamanism: A Reader, Routledge, Taylor \& Francis Group, London - New York, 301-306.

Hećimović-Seselja, Mara (1985): Tradicijski život i kultura ličkoga sela Ivčević Kosa. Mladen Seselja, Zagreb - Muzej Like, Gospić, Zagreb.

Henningsen, Gustav (1991/92): The White Sabbath and the Other Archaic Patterns of Witchcraft. Acta Ethnographica Hungarica (Special Issue: Witch Beliefs and Witchhunting in Central and Eastern Europe, Conference in Budapest, Sept. 6-9, 1988) 37/1-4: 293-304.

Hill, Douglas (1998): Vještice i čarobnjaci. Knjiga trgovina, Zagreb.

Hoppál, Mihály (1992): Traces of Shamanism in Hungarian Folk Beliefs. In: Anna-Leena Siikala - Mihály Hoppál. 1992. Studies on Shamanism, Finnish Anthropological Society, Akadémiai Kiadó (Ethnologica Uralica 2), Helsinki - Budapest, 156-168.

Hoppál, Mihály (1993): Shamanism: Universal Structures and Regional Symbols. In: Edited by Mihály Hoppál and Keith D. Howard with the assistance of Otto von Sadovszky and Taegon Kim, Shamans and Cultures, Akadémiai Kiadó, International Society for Trans-Oceanic Research, Budapest - Los Angeles, 181-192.

Hoppál, Mihály (1993a): Studies on Eurasian Shamanism. In: Edited by Mihály Hoppál and Keith D. Howard with the assistance of Otto von Sadovszky and Taegon Kim, Shamans and Cultures, Akadémiai Kiadó, International Society for Trans-Oceanic Research, Budapest - Los Angeles, 258-288.

Hruškovec, Tomislav (1998): Đavlu zapisane: o vješticama u Zagrebu i Hrvatskoj. Imprime, Zagreb.

Hughes, Pennethorne (1975/1952): Witchcraft. Penguin Books, London.

Huxley, Aldous Leonard (2001): Vrata percepcije; Raj i pakao. Zagrebačka naklada, Zagreb. Ilić Oriovčanin, Luka (1846): Narodni slavonski običaji. Franjo Suppan, Zagreb.

Jacobs, Katrien. Coyote Speaks in New York City, May 1974 (http://pages.emerson.edu/faculty/Katrien_Jacobs/articles/beuys/beuys.html).

Jakobsen, Merete Demant (1999): Traditional and Contemporary Approaches to the Mastery of Spirits and Healing. Berghahn Books, New York - Oxford.

Jardas, Ivo (1957): Kastavština. Zbornik za narodni život i običaje Južnih Slavena, 39, Zagreb.

Kadčić, Peka B. Petar (1859): Odgovori na njekoja pitanja družtva za jugoslavensku povjestnicu i starine. Iz kotara Makarskoga. Arkiv za povjestnicu jugoslavensku, Knjiga V [Vještica, Mora: str. 333-334], Zagreb.

Kazimirović, Radovan N. (1986/1940): Tajanstvene pojave u našem narodu. Kremansko proročanstvo. Čaranje, gatanje, vračanje i proricanje u našem narodu. Prilog ispitivanju tajanstvenih duhovnih pojava. Arion, Smederevo.

Klaniczay, Gabor (1984): Shamanistic Elements in Central European Witchcraft. In: ed. Mihály Hoppál, Shamanism in Eurasia 2:404-422, Göttingen.

Klečke vještice (http://www.ogulin.hr/ostalo/vjestice.htm).

Kotarski, Josip (1918): Lobor. Zbornik za narodni život i običaje Južnih Slavena, 23: [Vještice: str. 49-50], Zagreb.

Kutleša, Silvestar (1993): Život i običaji u Imockoj krajini. Matica hrvatska Ogranak Imotski, Imotski.

Lamarche-Vadel, Bernard (2003): Tko se boji Josepha Beuysa.In: ed. Ješa Denegri, Dossier Beuys, DAF, Zagreb, 115-124. 
Lecouteux, Claude (2003/1992): Witches, Werewolves, and Fairies: Shapeshifters and Astral Doubles in the Middle Ages. Translated by Clare Frock. Rochester, Vermont, Inner Traditions.

Levack, Brian P. 1995. The Witch-Hunt in Early Modern Europe. Second Edition. Longman, London and New York.

Lévi-Strauss, Claude (1989): Strukturalna antropologija. Stvarnost, Zagreb.

Lissner, Ivar (1961): Man, God and Magic. Translated from the German by J. Maxwell Brownjohn, m. a. (Oxon.). G. P. Putnam's Sons, New York.

Lovrenčević, Zvonko (1969-1970): Mitološke predaje Bilogore. Narodna umjetnost, 7: 71-100, Zagreb.

Luhrmann, T. M. (1989): Persuasions of the Witch's Craft: Ritual Magic in Contemporary England. Harvard University Press, Cambridge, Massachusetts.

Lulić, Jasenka (1993): Vjerovanje u "štrigu" na Dugom otoku. Zadarska smotra (Zborniko Dugom otoku), 1-2: 361-365, Zadar.

Marjanić, Suzana (1999): Zaštitna sredstva protiv more kao žensko-niktomorfnog demona. Treća: časopis Centra za ženske studije, 2/1: 55-71, Zagreb.

Marjanić, Suzana (2002): Astralna metla i levitacijski performansi vještičjega tijela. Treća: časopis Centra za ženske studije, 1/IV:226-249, Zagreb.

Marjanić, Suzana (2003): (Dyadic) the Goddess and Duotheism in Nodilo's The Ancient Faith of the Serbs and the Croats. Studia mythologica Slavica, 6: 183-205, Ljubljana.

Marjanić, Suzana (2004): Životinjsko u vilinskom. In: eds. Renata Jambrešić Kirin i Tea Škokić, Između roda i naroda: etnološke i folklorističke studije, Institut za etnologiju i folkloristiku, Centar za ženske studije, Biblioteka Nova etnografija, Zagreb, 231-256.

Marjanić, Suzana (2004a): Južnoslavenske folklorne koncepcije drugotvorenja duše i zoopsihonavigacije/zoometempsihoze. Kodovi slovenskih kultura, 9:208-248.

McKenna, Terence - Dennis McKenna. 1994. The Invisible Landscape: Minds, Hallucinogens and the I Ching. Harper, San Francisco.

Mencej, Mirjam (2004): Verovanja o svetlosnim pojavama na istočnom delu Slovenije. Kodovi slovenskih kultura, 9: 249-262.

Marks, Ljiljana (1980): Usmene pripovijetke i predaje s otoka Zlarina. Narodna umjetnost, 17: 217-280, Zagreb.

Mauss, Marcel (1982): Sociologija i antropologija I. Prosveta, Beograd.

Medić, Mojo (1928): Folklorističke dopune. Zbornik za narodni život i običaje Južnih Slavena, 26/2: 257-275. Zagreb.

Mikac, Jakov (1934): Vjerovanja (Brest u Istri). Zbornik za narodni život i običaje Južnih Slavena, 29:195-200, Zagreb.

Milčetić, Ivan (1896): Mora i polegač - a) Krk, Kastav, i hrvatski kajkavci. Zbornik za narodni život i običaje Južnih Slavena, I: 235-237, Zagreb.

Milčetić, Ivan (1896): Vjera u osobita bića. Otok Krk, i kajkavci. Zbornik za narodni život i običaje Južnih Slavena, 1:232-233, Zagreb.

Milčetić, Ivan (1896): Krk i Kastav u Istri. Zbornik za narodni život i običaje Južnih Slavena, 1:224-226, Zagreb.

Milićević Bradač, Marina. (2002): Of Deer, Antlers, and Shamans. In: ed. Petar Selem, Znakovi i riječi $=$ [Signa et litterae]: zbornik projekta "Protohistorija i antika hrvatskog povijesnog prostora", Hrvatska sveučilišna naklada (Zagreb: Kratis), Zagreb, $7-41$. 
Murray, Margaret A. (1970): The God of the Witches. Oxford University Press, Oxford. Musi, Carla Corradi (1997): Shamanism from East to West. Akadémiai Kiadó, Budapest. Nodilo, Natko (1981/1885-1890): Stara vjera Srba i Hrvata (Religija Srbâ i Hrvatâ, na glavnoj osnovi pjesama, priča i govora narodnog). Logos, Split.

Noll, Richard (1983): Shamanism and Schizophrenia: A State-Specific Approach to--459, Washington.

Ojamaa, Triinu (1997): The Shaman as the Zoomorphic Human. Folklore: Electronic Journal of Folklore Vol. 4 (www.folklore.ee/folklore/vol4/triinu.htm).

Pavić, Antun (1852): Odgovor na pitanja stavljena po družtvu. Arkiv za povjestnicu jugoslavensku, Knjiga II: 339-343, Zagreb.

Pederin, Marko (1976): Stara virovanja na zapadnom Pelješcu. Pelješki zbornik, 1: 271294, Split.

Petersdorff, Egon von (2001): Demoni, vještice, spiritisti: sve o postojanju i djelovanju mračnih sila. Verbum, Split.

Plant, Sadie (2004): Pisanje na drogama. Celeber, Zagreb.

Plotnikova, Anna A. (1999): "'Rubašečka' i 'postel'ka' novoroždennogo". Kodovi slovenski kultura, 4: 158-167, Beograd.

Plotnikova,Anna A.(2001):"Košuljica".In:eds.Svetlana M.Tolstoj-Ljubinko Radenković. Slovenska mitologija: enciklopedijski rečnik, Zepter Book World, Beograd, 291.

Pócs, Éva (1999): Between the Living and the Dead: A Perspective on Witches and Seers in the Early Modern Age. Central European University Press, Budapest.

Radenković, Ljubinko (1996): Narodna bajanja kod Južnih Slovena. Prosveta, Beograd.

Raudvere, Catharina (2002): Trolldómr in Early Medieval Scandinavia. In: eds. Bengt Ankarloo - Stuart Clark, Witchcraft and Magic in Europe. Vol. 3. The Middle Ages, The Athlone Press, London, 73-171.

Reid, Anna (2003): The Shaman's Coat: A Naive History of Siberia. Phoenix, London.

Sax, Boria (2001): The Mythical Zoo: An Encyclopedia of Animals in World Myth, Legend, \& Literature. ABC - CLIO, Santa Barbara, California - Denver, Colorado - Oxford, England.

Schaechter, Elio (1998): In the Company of Mushrooms. A Biologist's Tale. Harvard University Press, Cambridge, Massachusetts - London, England.

Schaffner, Willi (1999): Ljekovito bilje: kompendij. Leo-commerce, Rijeka.

Schneeweis, Edmund (2005/1961): Vjerovanja i običaji Srba i Hrvata. Golden marketing - Tehnička knjiga, Zagreb.

Shuttle, Penelope - Peter Redgrove (2002): Mudra krv: menstruacija i žena - mitovi, stvarnosti i značenja menstruacije. Gorin, Rijeka.

Siikala, Anna-Leena (2002): Mythic Images and Shamanism: A Perspective on Kalevala Poetry. Suomalainen Tiedeakatemia, Academia Scientiarium Fennica (FF Communications No. 280), Helsinki.

Starhawk (2000): Spiralni ples: preporod drevne religije Boginje. Liberata, Zagreb.

Stojanović, Mijat (1852): Odgovor na pitanja. Arkiv za povjestnicu jugoslavensku, Knjiga II: 346-403, Zagreb.

Stojković, Marijan (1929): Sito i rešeto u narodnom vjerovanju. Zbornik za narodni život i običaje Južnih Slavena, XXVII/I: 43-53, Zagreb.

Stojković, Marijan (1935): Sobna prašina, smeće, metla i smetlište. Zbornik za narodni život i običaje Južnih Slavena 30/1: 17-31, Zagreb. 
Stojnić, Damir. 2006. Performansi vatre \& Animalkemija. In: Zarez: dvotjednik za kulturna i društvena zbivanja, 181, 1 June 2006, Zagreb, 32-33.

Stutley, Margaret (2003): Shamanism: An Introduction. Routledge, Taylor and Francis Group, London - New York.

Sučić, Nikola (1943): Na izvoru života: naučna poglavlja za studente i naobražene laike. Spolni život, spolne bolesti i higiena braka. Treće, prošireno i nadopunjeno izdanje knjige. Tisak Hrvatske državne tiskare, Zagreb.

Szasz, Thomas S. (1982): Proizvodnja ludila: usporedno proučavanje inkvizicije i pokreta za brigu o duševnom zdravlju. GZH, Zagreb.

Šmitek, Zmago (1998): Kresnik: An Attempt at a Mythological Reconstruction. Studia mythologica Slavica, 1: 93-118, Ljubljana.

Šmitek, Zmago (1999): The Image of Real World and the World Beyond in the Slovene Folk Tradition. Studia mythologica Slavica, 2: 161-195, Ljubljana.

Šuvaković, Miško (1999): Pojmovnik moderne i postmoderne likovne umetnosti i teorije posle 1950. godine. SANU \& Prometej, Beograd - Novi Sad.

Tkalčić, Ivan (1891): Parnice proti vješticam u Hrvatskoj. Rad JAZU, 103: 3-36, Zagreb. Tokarev, Sergej A. (1978): Rani oblici religije i njihov razvoj. Svjetlost, Sarajevo.

Toporkov, A. L. (2001): "Stupa". In: eds. Svetlana M. Tolstoj - Ljubinko Radenković. Slovenska mitologija: enciklopedijski rečnik, Zepter Book World, Beograd, 515-517.

Toporkov, A. L. (2001): "Tučak". In: eds. Svetlana M. Tolstoj - Ljubinko Radenković. Slovenska mitologija: enciklopedijski rečnik, Zepter Book World, Beograd, 545-546.

Trebješanin, Žarko (2000): Predstava o detetu u srpskoj kulturi. Južnoslavenski centar za prava deteta, Beograd.

Veleckaja, Natalija Nikolaevna (1996): Mnogobožačka simbolika slovenskih arhajskih rituala. Prosveta, Niš.

Visković, Nikola (1996): Životinja i čovjek: prilog kulturnoj zoologiji. Književni krug, Split.

Visković, Nikola (2001): Stablo i čovjek: prilog kulturnoj botanici. Izdanja Antibarbarus, Zagreb.

Vukanović, T. P. (1971). Studije iz balkanskog folklora III. Vranjski glasnik, 7:165-274, Vranje.

Vitebsky, Piers (1995): The Shaman. Macmillan, London, Basingstoke.

Wallis, Robert J. (2001): Waking Ancestor Spirits: Neo-Shamanic Engagements with Archaelogy. In: ed. Neil S. Price, The Archaeology of Shamanism, Routledge, London - New York, 213-230.

Wallis, Robert J. (2003): Shamans/Neo-Shamans: Ecstasy, Alternative Archaeologies and Contemporary Pagans. Routledge, Taylor \& Francis Group, London - New York.

Zečević, Divna (1995): Remetska književna kronika (Usmena, pisana i tiskana). Narodna umjetnost, 32/2: 65-107, Zagreb.

Zečević, Slobodan (1978): Neki primeri šamanske prakse u istočnoj Srbiji. Etnološki pregled, 15: 37-43, Beograd.

Zečević, Slobodan (1981): Mitska bića srpskih predanja. "Vuk Karadžić" - Etnografski muzej, Beograd.

Žiža, Stjepan (1913): Grišnjak (Iz Istre). Zbornik za narodni život i običaje Južnih Slavena, 18/1: 192, Zagreb. 
Manuscripts (Institute of Ethnology and Folklore Research, Zagreb)

IEF MS 88. Bonifačić Rožin, Nikola 1952. Hrvatske narodne pjesme, priče i običaji iz kotara Poreč i okolice Rovinja.

IEF MS 118. Bonifačić Rožin, Nikola. 1953. Hrvatski narodni običaji, pjesme, priče iz kotara Pazin.

IEF MS 172. Bošković-Stulli, Maja. 1954. Folklorna građa iz Banije. Narodne pjesme, priče, običaji i drugo iz Banije, 1.

IEF MS 192. Fortunić, Vlaho. 1937. Iz narodne folklore o morama $i$ vješticama te o urocima i vukodlacima.

IEF MS 783. Bonifačić Rožin, Nikola. 1966. Folklorna građa otoka Korčule.

IEF MS 959. Milićević, Josip. 1977. Etnološka građa Lastova.

IEF MS 1127. Buljan, Ante. 1985. Opis običaja rodnog kraja Sinja, Imocki, Vrljika, Livna kao i pripadajuće okoline.

IEF MS 1142. Fučić, Branko. 1985. Zapisi narodnih predaja (vjerovanja) sa Cresa 1951.

IEF MS 1195. Livijo, Marijan. 1986. Običaji životnog ciklusa i godišnji običaji, predaje, kazivanja i vjerovanja u Velom Ižu 1986. $g$.

IEF MS 1218. Marks, Ljiljana. 1981. Predaje i ostala kazivanja s Lastova.

IEF MS 1608. Marjanić, Suzana. 1997. Folklorna građa s poluotoka Pelješca (mitološke / demonološke/, povijesne i etiološke predaje). 
Witches' zoopsychonavigations and the astral broom in the worlds of Croatian legends ......

\section{Vještičje zoopsihonavigacije i astralna metla u svjetovima hrvatskih predaja kao (mogući) aspekti šamanističke tehnike ekstaze (i transa)}

\section{Suzana Marjanić}

Polazeći od knjige Mythic Images and Shamanism: A Perspective on Kalevala Poetry (2002) u kojoj Anna-Leena Siikala, između ostaloga, apostrofira da šamanizam nije religija već kompleks obreda i vjerovanja u različitim religijama, vještičje zoopsihonavigacije u svjetovima hrvatskih predaja interpretiramo kao (moguće) aspekte šamanske tehnike ekstaze (i transa), u okviru čega pojmom zoopsihonavigacija nastojimo imenovati granicu prožimanja šamanskih ekstatičkih iskustava i vještičjih iskustava letargije. Pod pojmom zoopsihonavigacija (psihonavigacija duše u animalnoj egzistenciji), s jedne strane, promatramo zoometempsihoze (drugotvorenja duše u animalnom obličju) koje se odvijaju $\mathrm{u}$ iskustvima letargije nadnaravnih osoba i mitskih bića, s obzirom da metempsihoza zahtijeva transgresiju preko smrti - privremenu smrt. U okviru navedenoga koncepta zoo/ psihonavigacije promatramo i vještičju astralnu metlu koja se može interpretirati kao izomorfizam falomorfnoga aplikatora koji se podmazivao mastima što sadrže atropin, i kao izomorfizam šamanskoga konjskoga štapa (s ručkom u obliku konjske glave), što ga burjatski šamani rabe u ekstatičkim plesovima, koji se, uostalom, i naziva konj (a nije bez sličnosti s drškom vještičje metle), te figurira kao neka vrsta hobby-horsea, na kojemu šaman jašući, putuje u drugi svijet - ili Eliadeovim određenjem simboličko "jahanje" izražavalo je napuštanje tijela, "mističku smrt" šamana. Jednako tako pod pojmom zoopsihonavigacija razumijevamo i vještičje zoometamorfoze, kao i jahanje (let) na životinjama (teriomorfna vozila) kojima, primjerice, vještice lebde u zraku (riječ je o binomnoj anatomiji/ikonografiji Žena-Životinja) i, naravno, inkubna jahanja na muškarcima (koje dijele vile i vještice).

Primjerice, zoometempsihoza u muhu, koja je predajno pridana mòrama, vješticama i krsnicima, potezima moći na vlasti (u Sloterdijkovu određenju) eklezijastičkih autoriteta i pučkom etikom dijabolizirana je kada je riječ o mòrama i vješticama, a kada je pripisana krsnicima, promatra se u nadnaravnim svojstvima. Slična se etička diferencijacija ostvarila i u procesu pučke imaginacije o vještičjim zoometamorfozama koje su dijabolizirane, dok zoometamorfoze krsnika koje ostvaruju u psihonavigacijskim bojevima za rodnu godinu (u plodotvorne zaštitnike ulaze, primjerice, i obilnjaki, brganti, kombali, vedomci, moguti, vedi, vrimenjaci/vremenjaci, višćaci, legromanti/nagromanti, vjedogonje/jedogonje, stuhe, zduhači) razumijevane su kao plodotvorne.

Pored navedenoga koncepta zoopsihonavigacije, mogući dodiri između vještičarstva i šamanizma uspostavljeni su i na temelju mitema o šamanskom kao i vještičjem međusobnom agonu, osebujnoga rođenja (rođenja u košuljici), toposa axis mundi - mitska geografija planina i stabala (paralelizam između šamanskoga stabla i vještičjega/vilinskoga stabla), uporabom halucinogenih biljaka kao i svjetlosnim hipostazama vještičjega tijela u kontekstu Eliadeove atribucije šamana kao "gospodara vatre". 